\title{
The role of climate and aeolian dust input in calcrete formation in volcanic islands (Lanzarote and Fuerteventura, Spain)
}

\author{
Pedro Huerta a,*, Álvaro Rodríguez-Berriguete ${ }^{\text {b,c }}$, Rebeca Martín-García ${ }^{\text {b }}$, Andrea Martín-Pérez ${ }^{\text {d, }}$ \\ Ángel La Iglesia Fernández ${ }^{\mathrm{c}}$, Ana María Alonso-Zarza ${ }^{\mathrm{b}, \mathrm{c}}$ \\ a Departamento de Geología, Escuela Politécnica Superior de Ávila, Universidad de Salamanca, Avd/Hornos Caleros, 50, 05003 Ávila, Spain \\ b Departamento de Petrología y Geoquímica, Fac. CC. Geológicas, Universidad Complutense de Madrid, C/José Antonio Novais, 2, 28040 Madrid, Spain \\ c Instituto de Geociencias, IGEO (CSIC, UCM), C/José Antonio Novais, 2, 28040 Madrid, Spain \\ ' Institute of Palaeontology ZRC SAZU, Novi trg 2, SI 1000 Ljubljana, Slovenia
}

\section{A R T I C L E I N F O}

\section{Article history:}

Received 16 June 2014

Received in revised form 30 September 2014

Accepted 5 October 2014

Available online $\mathrm{xxx}$

\section{Keywords:}

Calcrete

Canary Islands

Geochemistry

Strontium

Vegetation

\begin{abstract}
A B S T R A C T
Calcretes are widely described in non-marine settings with carbonates in their catchment, or vicinity areas, but in volcanic islands without carbonates in their substrate, calcretes are not very common. In Lanzarote and Fuerteventura Canary Islands, characterized by impressive volcanic landscapes, the sedimentary carbonate rocks are rare except for some recent marine and aeolian deposits. In these settings very well-developed calcretes cover large areas of the present landscape. The source of calcium required for the formation of these calcretes has not been discussed in much detail till now, although its role is critical to an understanding of the climatic conditions in which calcium was transported and fixed and of the calcrete formation processes. The petrological and geochemical studies $\left({ }^{87} \mathrm{Sr} /{ }^{86} \mathrm{Sr}\right.$ ratios, $\delta^{13} \mathrm{C}, \delta^{18} \mathrm{O}$, major, trace and REE) carried out in this paper do confirm the important role of aeolian dust input in the formation of these calcretes. Canarian calcretes were mainly generated by pedogenic processes and are composed of various irregular carbonate lamina interbedded with fine clastic deposits. Our study indicates that these interbeddings were the result of several stages in which, during dry periods, aeolian dust deposition alternated with leaching and calcite precipitation during wetter periods when plants, insects and bacteria played an important role in carbonate precipitation. The $\delta^{18} \mathrm{O}(-2.70$ to $+2.22 \%$ 。 VPDB) and $\delta^{13} \mathrm{C}(-8.21$ to $+0.24 \%$. VPDB $)$ values indicate that calcretes were formed by pedogenic processes. Comparison of calculated $\Delta^{18} \mathrm{O}$ values for the Canary calcretes with continental mid-latitude calcrete values reflects the more homogeneous temperature regimes of calcrete formation in island (oceanic) settings. Calcrete ${ }^{87} \mathrm{Sr} /{ }^{86} \mathrm{Sr}$ ratios ( 0.706357 to 0.709208 ) show strong affinity with those obtained in aeolian carbonate dust and marine deposits, and are relatively different from those obtained in basalts. REE, major and trace element concentrations show that Ca-bearing minerals from volcanic host rock contributed little to calcrete formation and most of the calcium was supplied by aeolian deposits such as the aeolian dust coming from the Sahara and Sahel or sand dunes.
\end{abstract}

(C) 2014 Elsevier B.V. All rights reserved.

\section{Introduction}

Pedogenic calcretes are terrestrial carbonate materials whose formation, within a soil profile, results from the introduction of mostly vadose carbonate into soils, rocks or sediments (Goudie, 1973; Watts, 1980). Biogenic and non-biogenic mechanisms of calcium precipitation within calcretes have been widely discussed. In most cases it seems that semiarid climates favoured calcrete formation (Wright, 2007; Alonso-Zarza and Wright, 2010). However, the formation of thick calcrete profiles requires long periods of time under which, climate and soil organisms

\footnotetext{
* Corresponding author. Tel.: +34920353500.

E-mail addresses: phuerta@usal.es (P. Huerta), arberriguete@geo.ucm.es (Á. RodríguezBerriguete), rmarting@ucm.es (R. Martín-García), andreamartin@geo.ucm.es (A. MartínPérez), iglesia@geo.ucm.es (Á. La Iglesia Fernández), alonsoza@ucm.es (A.M. Alonso-Zarza).
}

may have varied (Wright, 2007). These variations, recorded in calcrete features, make calcretes an important palaeoenvironmental archive. Most of the palaeoenvironmental information extracted from calcretes is contained in their macro- and micro-morphological features, their biological content or their carbon and oxygen isotope signatures (Tanner, 2010). Weathering of parent-rocks, local inputs from nearby calcareous deposits, the biota, aeolian dust or sea spray in coastal areas have been considered as the main sources of Ca (Goudie, 1983; Capo and Chadwick, 1999; Cailleau et al., 2004). The strong chemical affinity of $\mathrm{Sr}$ and Ca makes ${ }^{87} \mathrm{Sr} /{ }^{86} \mathrm{Sr}$ ratio a good tracer for Ca provenance (Dart et al., 2007). Several studies using that ratio have shown that in most cases the contribution of Ca from weathering of the host rock seems to be very limited in comparison with the contribution of Ca from aeolian dust or atmospheric input (Chiquet et al., 1999), even in the presence of nearby carbonate formations (Hamidi et al., 2001). Determining the provenance of Ca may provide information on the 
atmospheric conditions and pathways that allowed Ca transport, and in cases where calcretes developed on siliceous rocks, the weathering of these rocks consumes $\mathrm{CO}_{2}$, so calcretes may play a role as a natural sink for $\mathrm{CO}_{2}$ (Lal and Kimble, 2000).

The eastern Volcanic Canary Islands, Lanzarote and Fuerteventura (Fig. 1) are an excellent laboratory for the study of Ca sources and geochemical mechanisms for the accumulation of calcium carbonate within the thick pedogenic calcrete profiles (Alonso-Zarza and Silva, 2002). In some cases, calcretes developed directly on the volcanic host rock, in the apparent absence of older carbonates in the surroundings. In other cases calcretes developed on alluvial-fan volcanic-sourced clastic deposits or on bioclastic aeolian deposits (Genise et al., 2013). As a result of island proximity to the Sahara desert, they are regularly affected by dust (Menéndez et al., 2007) sourced from northern Africa, the largest source area on earth for mineral dust (Goudie and Middleton, 2001; Laurent et al., 2008; Scheuvens et al., 2013). Several Ca sources can be considered in these islands, 1) the basalt plagioclases, 2) the Sahara and Sahel wind-blown dust (Coudé-Gaussen and Rognon, 1988; Mizota and Matsuhisa, 1995; Muhs et al., 2010), 3) marine sands during the last glacial (Coudé-Gaussen and Rognon, 1988), and 4) marine spray (Hamidi et al., 1999; Whipkey et al., 2000).

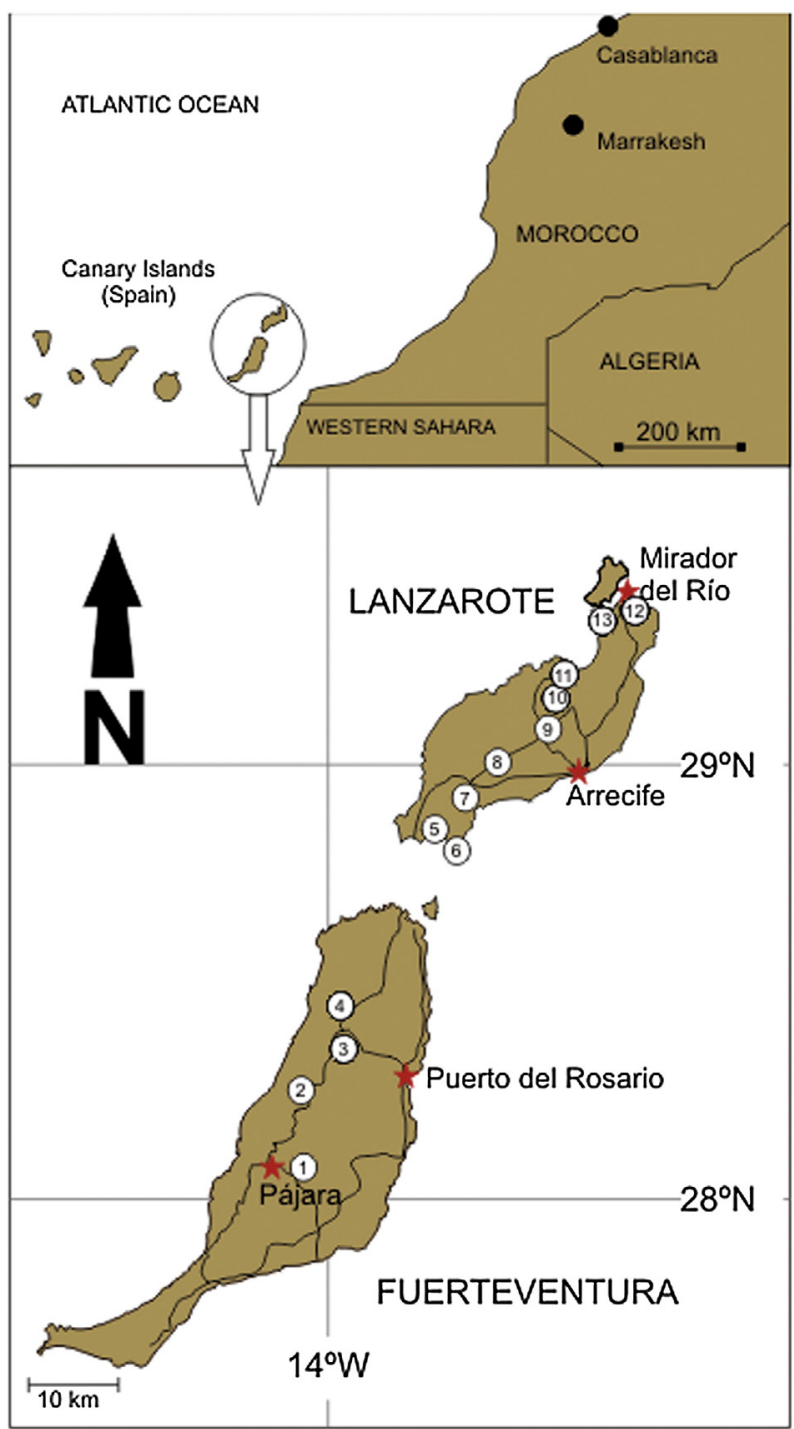

Fig. 1. Map showing the location of the Canary Islands and the outcrops studied in Lanzarote and Fuerteventura Islands (1. P. del Holandés; 2. Betancuria: 3. Ampuyenta; 4. Tefía; 5. Playa Blanca; 6. Pta. Papagayo; 7. Femés; 8. Macher (IES Basalt; IES Yaiza); 9. S. Bartolomé; 10. Tao; 11. Jable; 12. Mirador del Río; 13. Ye).
The aim of our study is to unravel how calcium is supplied to calcretes, and to discuss their palaeoclimatic significance. In this paper we perform mineralogical, petrological, including macro- and micromorphological features, and geochemical $\left({ }^{87} \mathrm{Sr} /{ }^{86} \mathrm{Sr}, \delta^{13} \mathrm{C}, \delta^{18} \mathrm{O}\right.$, major, trace and REE) analyses of various calcretes selected from Lanzarote and Fuerteventura Islands. The varied host rock in which the calcretes developed under the influence of the Saharian dust, makes them unique to understand the mechanisms of calcrete formation in volcanic settings.

\section{Geological setting}

The Canary Islands are a volcanic archipelago (Fig. 1) which lies on the continental margin of the Africa plate, on oceanic crust of early Jurassic age (Schmincke et al., 1998; Steiner et al., 1998a, 1998b; Ancochea et al., 2004; Carracedo et al., 2008). The origin of the islands is attributed to the activity of a hot spot. Age of the islands decreases from East to West. The younger islands are about $1.2 \mathrm{Ma}$, whereas the eastern-most islands, Lanzarote and Fuerteventura, situated closer to Africa, are about 20-21 Ma (Carracedo et al., 1998; Carracedo et al., 2002, 2008; Hoernle and Carracedo, 2009).

Lanzarote and Fuerteventura are in a senile evolutive stage dominated by erosive and sedimentary morphologies and processes, containing a large variety of marine, aeolian deposits and calcretes (Meco, 2008). Age of these deposits ranges from Pliocene to present times. Reworking of Quaternary bioclastic marine deposits by prevailing winds transporting sand grains gives place to the formation of large dune fields in the eastern-most Canary Islands during the more arid glacial periods. On the contrary, calcretes were formed after the Pliocene in the relatively less arid interglacial periods (Criado, 1988; Alonso-Zarza and Silva, 2002; Genise et al., 2013). Palaeoclimatic trends for the eastern Canary Islands were established on the basis of previous pedological, sedimentological, and palaeoecological studies (Petit-Maire et al., 1987; Damnati, 1997; Zazo et al., 1997; Meco et al., 2011).

Present-day climatic conditions reflect the scarcity of water, and predominant arid conditions within Lanzarote and Fuerteventura. Their climate is controlled by the cold Canary Current, which reduces precipitation and causes high temperatures equivalent to those recorded in the Western Sahara. Both islands have a mean annual precipitation of $105 \mathrm{~mm}$. Marine trade winds affect the Canary Islands during most of the year and the scarce precipitation is mostly brought by westerly cyclones occasionally following southern tracks (Damnati, 1997; von Suchodoletz et al., 2009). At present the islands receive important amounts of Saharian dust. In winter the dust is brought by the "Calima" low-level continental African winds, which are deflected towards the northwest by Atlantic cyclones (Criado and Dorta, 2003). The northern branch of the high altitude Saharian Air Layer (SAL) transports the dust to latitudes north of the Canary Islands mostly during the summer (Prospero and Lamb, 2003). The main direction of dust transport in the SAL is to the west at latitudes between $15^{\circ}$ and $21^{\circ} \mathrm{N}$ (south of the Canary Islands). A south-to-north component of flow can occur in the lee of an easterly wave (Pye, 1987; Muhs et al., 2010). Part of the dust carried by the SAL sinks into the lower atmosphere and is transported to the islands by northeast trade winds (Bozzano et al., 2002; von Suchodoletz et al., 2009; von Suchodoletz et al., 2010).

\section{Methods}

Samples were taken from different calcrete profiles representative of the entire variety of host rock on which calcrete developed and in selected points of Lanzarote and Fuerteventura Islands to check the possible changes in aeolian dust distribution (Fig. 1). Some profiles were previously studied because of their content in insect trace fossils (Genise et al., 2013). Thin sections were done to perform the petrographical analysis and to characterize the textures and microstructures.

Mineralogical composition of bulk-rock samples was determined by $\mathrm{X}$-ray diffraction using a Bruker D8 diffractometer equipped with a 
Sol-X detector. Quantitative analyses were performed using EVA software by Bruker.

The $\delta^{13} \mathrm{C}$ and $\delta^{18} \mathrm{O}$ values of 23 powdered samples were analyzed at the Serveis Cientificotècnics of the Universitat de Barcelona. The samples, obtained with a small-drill $(0.5 \mathrm{~mm}$ in diameter) to minimize mixing minerals, were then washed with $100 \%$ phosphoric acid at $70{ }^{\circ} \mathrm{C}$ for $3 \mathrm{~min} . \mathrm{CO}_{2}$ was extracted using a Thermo Finnigan Carbonate Kiel Device III isotopic analyser with a Thermo Finnigan MAT-252 spectrometer, according to the McCrea (1950) method. Values obtained were corrected using the NBS-19 and NBS-18 standard for $\delta^{13} \mathrm{C}$ and the standard NBS-19 for $\delta^{18} \mathrm{O}$. Results are expressed in parts-perthousand (\%०) referred to VPDB standard. Reproducibility obtained was better than $0.03 \%$. Radiogenic ${ }^{87} \mathrm{Sr} /{ }^{86} \mathrm{Sr}$ isotope analysis was performed at the Geochronology and Isotope Geochemistry facility of the Universidad Complutense de Madrid using a VG TIMS mass spectrometer. A small-drill ( $0.5 \mathrm{~mm}$ in diameter) was used to avoid mixing different minerals. Samples were dissolved in $2.5 \mathrm{~N} \mathrm{HCL}$, centrifuged and then evaporated. Residue was again dissolved in $2.5 \mathrm{~N} \mathrm{HCL}$. The analytical precision for ${ }^{87} \mathrm{Sr} /{ }^{86} \mathrm{Sr}$ analysis is $0.01 \%$.

Major, minor and REE elements were determined by Acme Analytical Laboratories, Vancouver, Canada, using ICP-ES and ICP-MS. LOI was determined by weight difference after ignition al $1000{ }^{\circ} \mathrm{C}$ at the same laboratories. Analytical methods and detection limits can be found at www.acmelab.com.

\section{Calcrete profiles}

Profiles studied in selected areas of Lanzarote and Fuerteventura Islands (Fig. 1) are representative of the entire variety of host rock on which calcrete developed. Some profiles were previously studied because of their content in insect trace fossils (Genise et al., 2013).

\subsection{IES-basalt and IES-Yaiza}

These profiles, from the vicinity of Macher village (Lanzarote), $2.7 \mathrm{~km}$ from the southeast coast, $200 \mathrm{~m}$ above mean sea level (amsl), differ in their host rock. IES-Basalt profile ( $2.5 \mathrm{~m}$ thick) is developed on basalt, whereas IES Yaiza (1.9 m thick) is developed on lapilli deposits. The bottom of the IES-Basalt profile consists of $2-3 \mathrm{~cm}$ thick calcite-filled cracks within the basalt host rock. Towards the top of the profile, cracks connect and isolate basalt blocks (Figs. 2 and 3A). The hardest top-most part of the IES-Basalt profile displays sub-horizontal surfaces which delimit fusiform or wedge-shaped carbonate laminae, composed of $2-3 \mathrm{~cm}$ thick beds of laminar calcrete, separated by powdery carbonate with ooids, root marks and insect trace fossils. These beds of laminar calcrete dip downslope more than the terrain slope and sometimes show undulations (Fig. 3B).

The lower parts of IES-Yaiza profile are made up of basalt fragments with sizes around 4-7 cm in diameter coated by millimetric carbonate crusts. These coated clasts occur in a diffuse carbonate matrix. Very porous overlying lapilli deposits are diffusely cemented. The top-most of the profile consists on $0.2-4 \mathrm{~cm}$ thick beds of laminar calcrete.

\subsection{Mirador del Río}

Measured sections of Mirador del Río profiles (about $1 \mathrm{~m}$ thick), in north-western Lanzarote (Fig. 1), develop on reddish-brown weathered lapilli (clay-silt), have their base made up of a network of carbonate veins and/or of calcified root moulds (about $0.5 \mathrm{~cm}$ in diameter) that
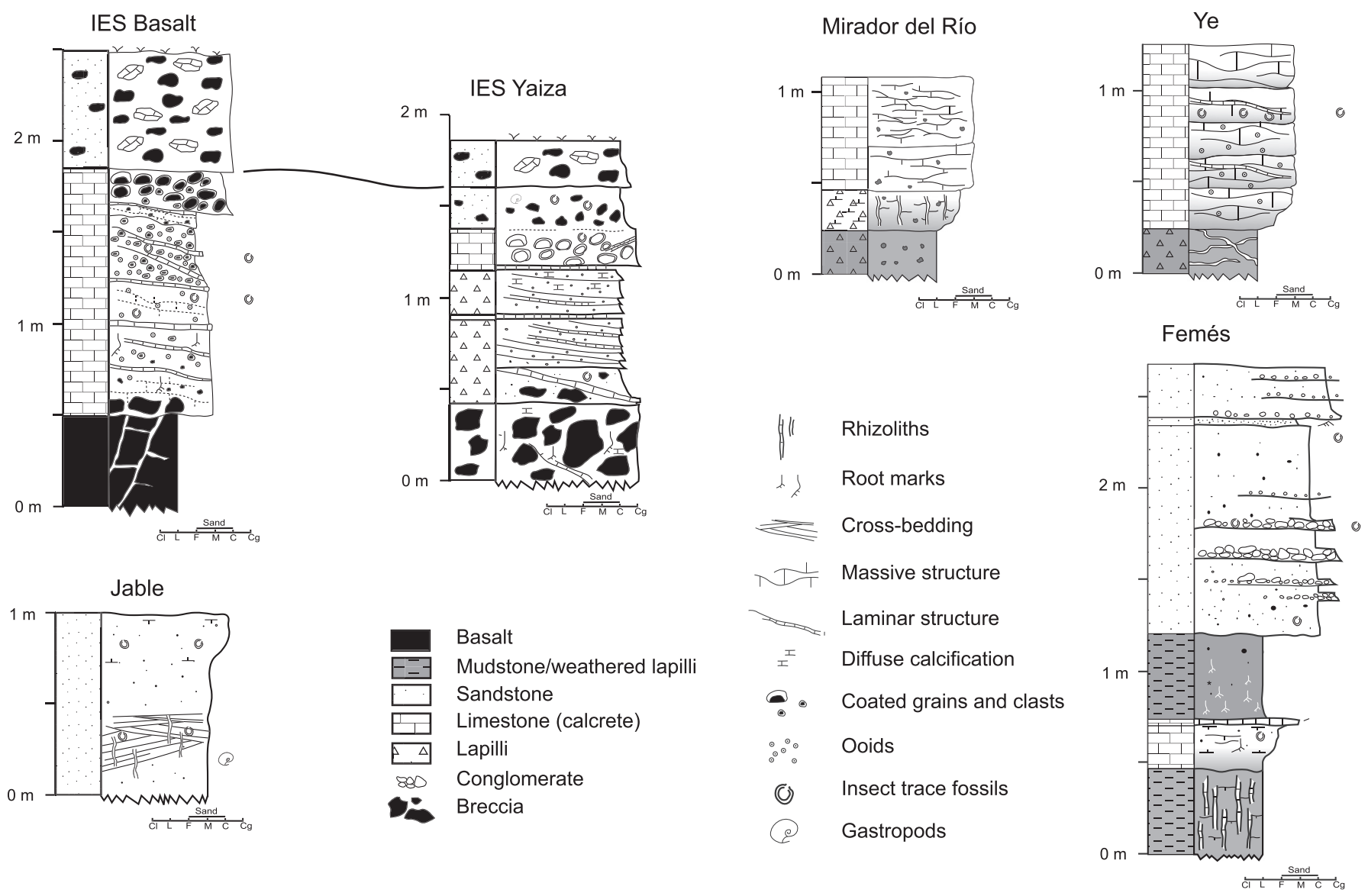

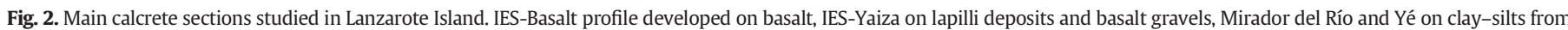
weathered lapilli, Jable on aeolian sands, and Femés on clay-silts from loess/alluvial deposits. 

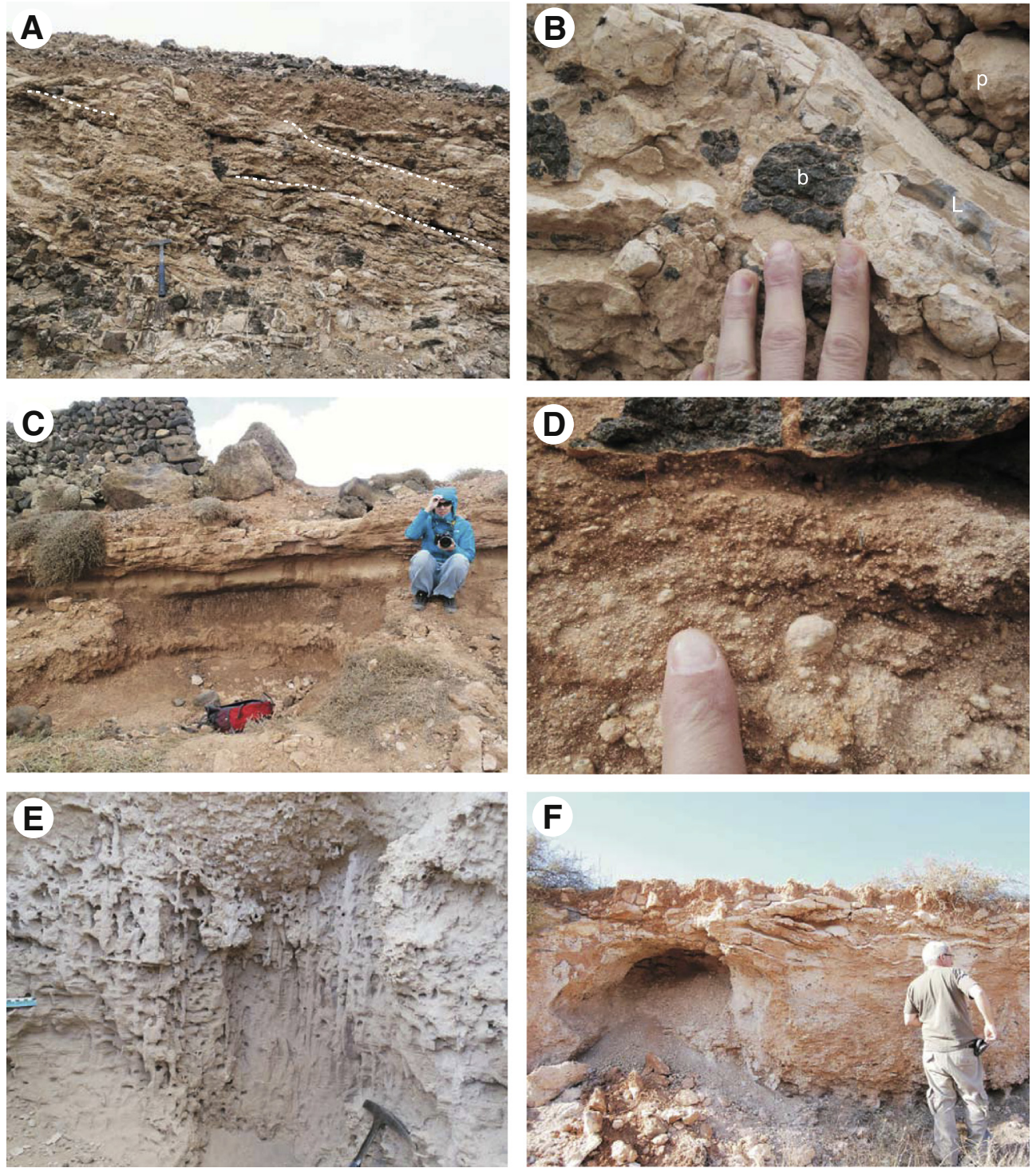

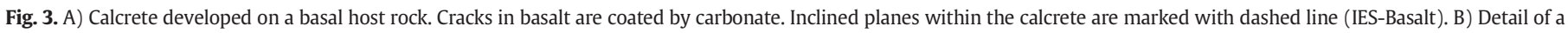

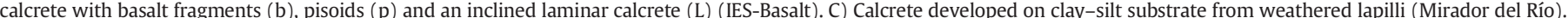

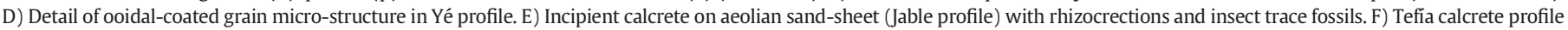
with irregular carbonate lamina. J. Genise for scale.

penetrate the weathered lapilli. Carbonate content in the calcrete increases towards the top of the profile, taking on a pink colour, where abundant vertical root-marks form a prismatic structure (Fig. 3C). Very abundant horizontal planes are also marked by carbonate accumulations. The vertical and horizontal carbonate network delimits prismatic blocks of weathered lapilli diffusely cemented by carbonate (Fig. 2). The top-most of the profile is a $0.5-0.7 \mathrm{~m}$ thick, pink, massive calcrete with undulating sub-horizontal planes (Fig. 3C). Insect trace fossils can be recognized in the weathered lapilli as well as in the massive calcrete.

\subsection{Yé}

Yé profile (1-1.2 m thick) locates in north-west Lanzarote and is developed on weathered lapilli (clay-silt) of the old Corona volcano (Fig. 1).

Its lower part is made up of red mudstones containing a carbonate network that grades upwards into several sequences with an upwardsincrease in carbonate content (Fig. 2), evidenced by a colour change from pink to white. Structure of the profile is massive but with several dipping beds of intercalated laminar calcrete. These inclined beds of laminar calcrete are dip more than the calcrete surface slope. The main texture distinguished in the massive part of the calcrete is the ooidal or coated-grain texture widespread across the massive calcrete (Fig. 3D).

\subsection{Jable}

The Jable profile ( $1 \mathrm{~m}$ thick) in northern Lanzarote developed on an aeolian sand sheet close to Caleta de Famara village (Fig. 1). The profile, $3 \mathrm{~km}$ from the coast, $70 \mathrm{~m}$ above sea level, dates from about $12 \mathrm{Ka} \mathrm{BP}$, based on amino-acid racemisation (Ortiz et al., 2006). These sand deposits, from the northern coast, are made up of well-sorted bioclastic sands with low-angle cross-stratification disrupted, in most of the profile, by vertical rhizoliths and large numbers of insect trace fossils (Genise et al., 2013) (Figs. 2 and 3E). These insect trace fossils and terrestrial snails are heavily coated by carbonate, whereas the aeolian sands are weakly carbonate cemented.

\subsection{Femés}

On Los Ajaches Massif, in the south of Lanzarote, Femés profile ( $0.8 \mathrm{~m}$ thick) developed on the Quaternary red loess deposited in a 
SW-NE palaeo-valley of almost $3 \mathrm{~km}$ in length and about $1 \mathrm{~km}$ in width (Fig. 1). This valley was dammed during the last 1.0 Ma due to volcanic activity in the area (Coello et al., 1992). As a consequence of damming, Femés acted as an aeolian dust sediment trap (von Suchodoletz et al., 2009).

Femés profile has a lower part of red silts with a carbonate-filled crack network and rhizoliths. Carbonate content increases upwards and forms a white massive horizon with sub-horizontal cracks, vertical root marks and insect trace fossils (Fig. 2). The massive horizon is capped by a centimetric laminar calcrete.

\subsection{Tefía}

This profile (1.75 m thick) developed in Fuerteventura Island, $1 \mathrm{~km}$ to the south of Tefía village, is Pleistocene in age (Alonso-Zarza and Silva, 2002). It developed on coarse gravels composed of volcanic fragments and is made up of: a) a lower massive, powdery horizon; b) an intermediate horizon formed by centimetre-thick interbedding of fine red mudstone deposits with thin irregular carbonate laminae, c) a bed of red mudstone with trace fossils at the bottom of the upper horizon and laminated carbonate at the top. The entire profile contains abundant trace fossils and calcified rootlets (Fig. 3F).

\subsection{Parque del Holandés}

Situated north of Parque del Holandés (Fuerteventura) housing development, this profile (1.40 m thick) developed on Pleistocene wellsorted medium-sized sands (Balcells Herrera et al., 2006). The sands consist of bioclasts, quartz and scarce volcanic grains. This profile is characterized by a pisolithic horizon in which the nuclei of the pisoliths are trace fossils (Genise et al., 2013). Calcified rootlets and thin laminar and irregular layers of carbonate are also common.

\section{Calcrete petrology}

The calcretes studied show a wide variety of micro-fabrics. In lower horizons, in direct contact with host rock, or in poorly developed profiles, such as Mirador del Río, or Jable, micro-fabrics are dominated by host rock characteristics, with little carbonate content. In the upper horizons, commonly laminar at outcrop scale, the amount of carbonate is such that it erases most host rock features. In this description we will deal first with
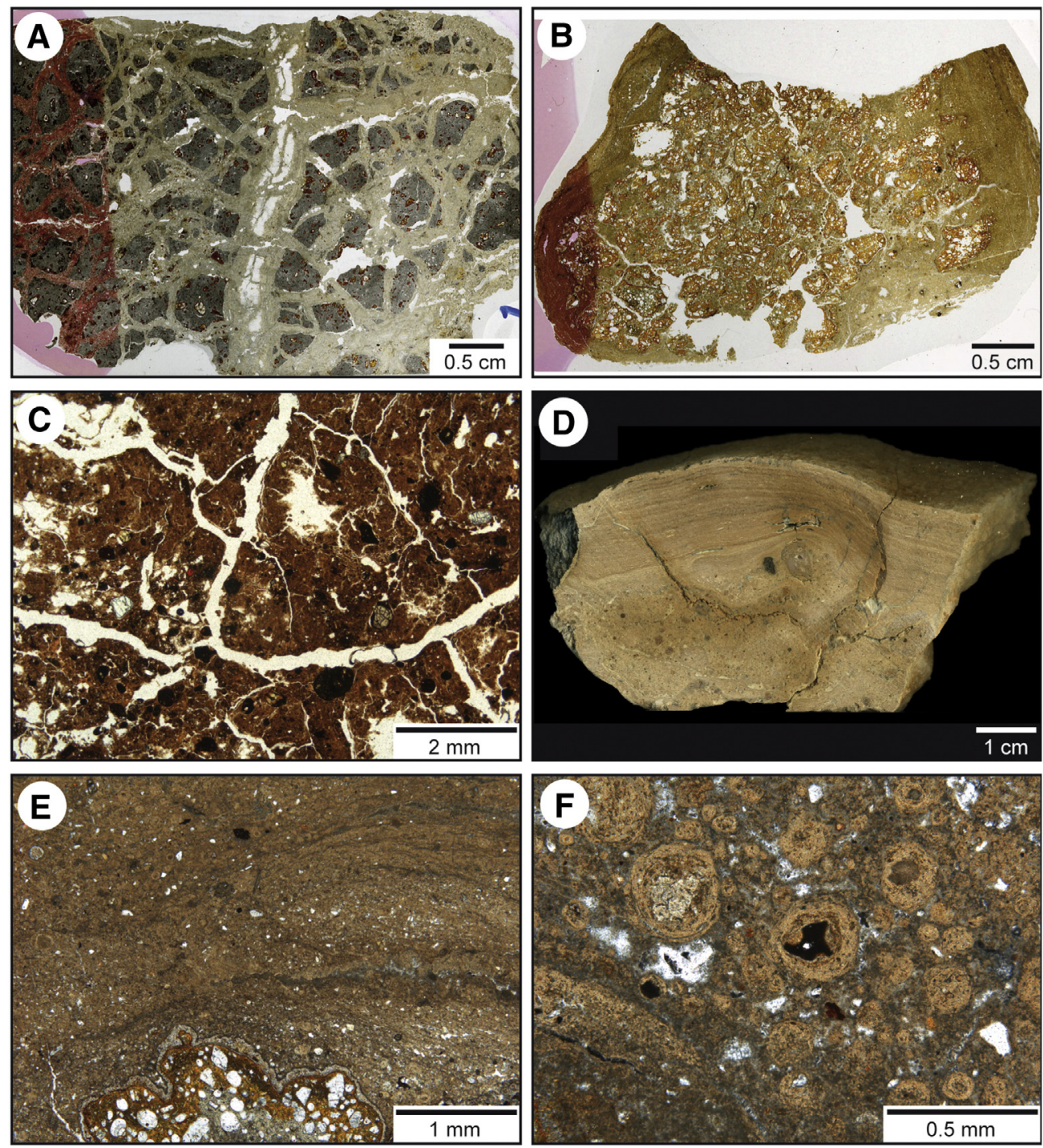

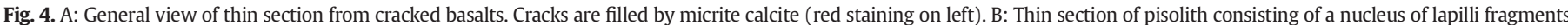

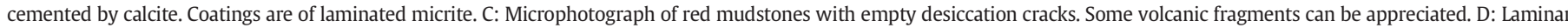

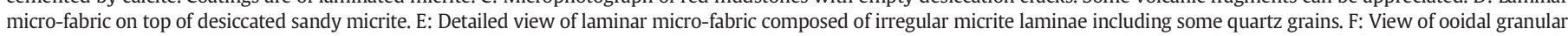
micro-fabric. Ooids are composed of nuclei of various types (quartz, micrite, volcanic grains ...) enveloped by thin micritic laminae. 
the micro-fabrics which contain more than $50 \%$ of host rock (referred to as host rock-dominated micro-fabrics) and later to the calcretedominated micro-fabrics which have less than $50 \%$ host rock minerals.

\subsection{Host rock-dominated micro-fabrics}

These micro-fabrics vary depending on the host rock and include:

A) Cracked basalts with carbonate laminae. These basalts show a dense network of planar cracks developed in all directions (Fig. 4A). The number and width ( $\mathrm{cm}$ to $\mathrm{mm}$ ) of cracks increase from the base to the top of the lower horizon (IES-Basalt profile). Basalt fragments are angular and range in size from $\mathrm{dm}$ to $\mathrm{mm}$. Some volcanic grains are weathered to clays in their external parts. Cracks are filled by laminated micrite which has alveolar septal structures, needle fibre calcite and peloids. In the innermost areas some cracks contain larger calcite crystals (about $1.5 \mathrm{~mm}$ across) arranged parallel to the cracks. Some opal is also found in the laminated micrite.

B) Cemented lapilli fragments are irregular and with varied morphologies, and in cases show a first opaline coating. Thin micrite laminae coat either the lapilli fragments or the opaline coating (Fig. 4B).
The space left between coated fragments is filled by micrite, thin fibrous calcite cement and peloids. Peloids are homogeneous, generally rounded and from $0.01 \mathrm{~mm}$ to $0.2 \mathrm{~mm}$ across.

C) Red mudstones with desiccation cracks are composed of clays, micrite and an isotropic vitreous mass, and include a large number of fragments of volcanic rocks, $0.1-10 \mathrm{~mm}$ across. Some fragments display orange coatings of micrite and clay. Mudstones are traversed by a very irregular network of desiccation cracks that fracture original host rock. Cracks are either empty or filled with carbonate (Fig. 4C). Most are desiccation cracks that in some cases were enlarged by root activity, giving rise to irregular and wider cracks ( $2 \mathrm{~mm}$ ) filled by a mass of micritic filaments and needle-like calcite crystals.

D) Aeolian sands with micritic coatings. Sand grains $(0.2$ to $0.5 \mathrm{~mm}$ in size) are bioclasts, quartz, fragments of volcanic rocks, and a few olivines and pyroxenes. Micrite coatings on the grains are mostly constructive, but in some cases penetrate grains and may contain some clay and iron oxides. Coatings are relatively irregular and in some cases show micritic filaments which may connect different coatings. Space between grains is either empty or partially filled by micrite or microspar. Irregular, tubular-to-spheroidal masses of micritic carbonate occur amongst grains. These masses are up

Table 1

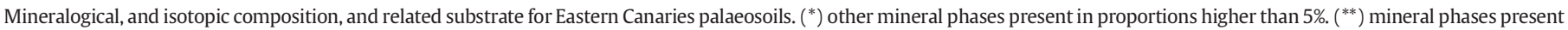

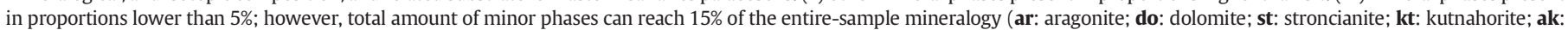
ankerite; gy: gypsum; ep: epsomite; ha: halite; cp: clinopyroxene; fd: foids: Fe-ox: iron oxides and hydroxides).

\begin{tabular}{|c|c|c|c|c|c|c|c|c|c|c|}
\hline Sample & Calcite & Quartz & Feldspar & Phyllosilicates & $\begin{array}{l}\text { Other mineral phases } \\
(>5 \%)^{*}\end{array}$ & $\begin{array}{l}\text { Trace mineral phases } \\
(<5 \%)^{* *}\end{array}$ & $\delta^{13} \mathrm{C}(\mathrm{V}-\mathrm{PDB})$ & $\delta^{18} \mathrm{O}(\mathrm{V}-\mathrm{PDB})$ & ${ }^{87} \mathrm{Sr} /{ }^{86} \mathrm{Sr}$ & Host rock \\
\hline FEM-1 & 20 & 8 & 15 & 48 & & do gy ep fd & & & 0.707173 & Clay-silt \\
\hline FEM-2 & 2 & 12 & 24 & 55 & & do st kt ak fd & & & 0.707781 & \\
\hline FEM-3 & 10 & 21 & 29 & 35 & & do fd & & & & \\
\hline FEM-4 & 1 & 19 & 42 & 34 & & $\mathrm{fd}$ & & & & \\
\hline FEM-5 & 52 & 8 & 12 & 23 & & do kt fd & & & 0.707938 & \\
\hline FEM-6 & 1 & 18 & 33 & 31 & & do st kt ak cp fd & & & 0.708304 & \\
\hline MAC-2 & 56 & 3 & 15 & 11 & $\mathrm{cp}(7)$ & ar do fd & -8.21 & -2.7 & 0.708593 & Basalt \\
\hline MAC-2-3 & 90 & 6 & 4 & - & & do & -4.86 & 0.22 & 0.708051 & \\
\hline MAC-2-4 & 60 & 2 & 7 & 15 & $\mathrm{cp}(9)$ & ar do kt ak Fe-ox & -5.7 & -1.24 & 0.707606 & \\
\hline MAC-2-5 & 60 & 2 & 14 & 14 & cp (6) & ar do st kt Fe-ox & -5.1 & -0.69 & 0.708068 & \\
\hline MAC-2-6 & 64 & 3 & 6 & 15 & $\mathrm{cp}(7)$ & ar st Fe-ox & -5.18 & -0.58 & 0.708538 & \\
\hline MACBAS & 13 & - & 40 & 10 & cp (20) Fe-ox (7) & ar do st kt ak fd & & & 0.703317 & \\
\hline IES-1 & 25 & 4 & 28 & 30 & ak (5) & ar do kt fd & & & & \\
\hline IES-2A & 34 & 2 & 22 & 17 & do (6) ak (7) cp (7) & ar do st fd Fe-ox & & & & \\
\hline IES-2B & 26 & 6 & 16 & 24 & $\mathrm{ak}(5) \mathrm{cp}(12)$ & ar do kt fd Fe-ox & & & & \\
\hline IES-4 & 58 & 4 & 18 & 14 & $\mathrm{cp}(6)$ & ar do fd Fe-ox & & & & \\
\hline IES-5 & 67 & 4 & 7 & 14 & cp (6) & ar do fd Fe-ox & & & & \\
\hline IESBAS-1 & 60 & 1 & 12 & 16 & cp (6) & ar do Fe-ox & & & & \\
\hline IESBAS-2 & 39 & 2 & 17 & 17 & cp (10) & ar do st kt ak fd Fe-ox & & & & \\
\hline IESBAS-5 & 55 & 6 & 9 & 16 & $\mathrm{cp}(7)$ & ar do kt ak fd Fe-ox & & & & \\
\hline IES-Y & 40 & 1 & 24 & 14 & $\mathrm{cp}(13) \mathrm{Fe}-\mathrm{ox}(6)$ & ar cp fd & & & 0.706357 & \\
\hline MR-00 & 1 & 14 & 15 & 44 & $\mathrm{Fe}-\mathrm{Ox}(5)$ & ar do st kt ak cp, fd & & & 0.708327 & Clay-silt \\
\hline MR-1 & 24 & 11 & 13 & 21 & do (5) ak (6) cp (8) & arag st kt ha, fd Fe-ox & -6.33 & -0.08 & 0.707842 & \\
\hline MR-02 & 18 & 10 & 15 & 33 & $\operatorname{ar}(7)$ & kt ak ha cp fd Fe-ox & & & & \\
\hline MRV-1 & 5 & 4 & 10 & 26 & kt (5) ak (11) cp (33) & ar kt ha fd Fe-ox & & & 0.708013 & \\
\hline PolvoPar & 1 & 23 & 18 & 41 & $\mathrm{cp}(7)$ & ar do kt ak fd Fe-ox & & & 0.709224 & Basalt \\
\hline PAP-1-E & 75 & - & 4 & 7 & do (10) & ar kt fd Fe-ox & -3.11 & -1.11 & 0.708949 & Aeolian and/or marine \\
\hline PAP-1-C & 60 & 2 & 11 & 25 & & do Fe-ox & -4.96 & -2.29 & 0.709009 & \\
\hline JABLE C & 25 & 1 & 9 & 18 & Fe-ox (7) & ar do kt fd & & & 0.709055 & Aeolian \\
\hline JAB-C-3 & 11 & - & 18 & 2 & ar (19) Fe-ox (7) & do kt gy ep cp & 0.24 & 0.4 & 0.709134 & Aeolian \\
\hline TAO-A-1 & 37 & 1 & 10 & 18 & $\operatorname{ar}(17) \mathrm{Fe}-\mathrm{ox}(11)$ & do kt fd & -1.81 & -0.27 & 0.709131 & Aeolian \\
\hline SB-2 & 32 & 1 & 26 & 17 & $\mathrm{cp}(17)$ & ar do kt fd & -6.87 & -1.24 & 0.706908 & Volcaniclastic gravel \\
\hline PHPIS-1 & 43 & 7 & 31 & 11 & & ar do st kt cp fd Fe-ox & -2.17 & 2.22 & 0.709208 & Aeolian \\
\hline PHPIS-2 & 49 & 2 & 22 & 21 & & ar do st cp Fe-ox & -3.84 & 0.79 & 0.709166 & \\
\hline TF-1 & 71 & 1 & 6 & 9 & $\mathrm{cp}(9)$ & ar do kt Fe-ox & -7.19 & -1.6 & 0.707311 & Volcaniclastic gravel \\
\hline $\mathrm{TF}-2$ & 56 & 3 & 17 & 18 & & ar do kt fd Fe-ox & -6.97 & -2.34 & 0.709003 & \\
\hline TF-5 & 88 & 4 & - & 5 & & do & -4.82 & 0.08 & 0.708567 & \\
\hline YE-1 & 55 & 2 & 9 & 15 & & ar do st kt ak cp fd Fe-ox & -5.79 & -0.8 & 0.70882 & Clay-silt \\
\hline YE-3 L & 60 & 2 & 15 & 13 & & ar kt cp Fe-ox & -6.81 & -1.33 & 0.70869 & \\
\hline YE-3 M & 43 & 1 & 9 & 17 & do (7) ak (6) cp (8) & ar kt fd Fe-ox & -5.72 & -0.48 & 0.708363 & \\
\hline YE-5 & 74 & 11 & - & 15 & & & -8.1 & -1.54 & 0.708645 & \\
\hline BET-1 & 66 & 1 & 11 & 12 & & ar do st kt gy ep fd Fe-ox & -7.65 & -2.3 & 0.708685 & Sienite \\
\hline AMP-2 & 70 & 7 & - & 18 & do (6) & & -5.42 & 0.01 & 0.708801 & Clay-silt \\
\hline PB-1 & 85 & 6 & - & 9 & & & -4.2 & -1.65 & 0.708861 & Clay-silt \\
\hline
\end{tabular}


to $2 \mathrm{~cm}$ across and contain alveolar septal structures and microspar microtubules.

\subsection{Calcrete-dominated micro-fabrics}

A) Desiccated sandy micrite consists of a relatively homogeneous sandy micrite (Fig. 4D) cut by irregular and commonly empty circum-granular desiccation cracks. There are some sand-tofine-gravel clasts, either of quartz, volcanic fragments, or rarely bioclasts. Some of these grains show irregular micritic coatings. In some cases the micrite groundmass is not homogeneous and consists of very tiny $(0.01 \mathrm{~mm})$ rounded peloids.

B) Laminar micro-fabrics (Fig. 4D-E) are the most characteristic of the calcretes and characterize both the laminar and the pisolithic horizons. The micro-fabric is composed of mm-irregular laminae of different types: micritic, ooidal, peloidal. They also contain siltsized calcite crystals and quartz grains.

C) Granular micro-fabrics are composed of various types of micrite grains (peloids, ooids, and intraclasts) either embedded in desiccated micrite or forming the entire calcrete. Intraclasts are homogeneous micritic grains (sand-to-fine gravel sized). Peloids are also composed of homogeneous micrite but in this case, rounded and small $(<0.1 \mathrm{~mm})$. Ooids are well-rounded carbonate grains, with a nucleus of micrite, quartz, volcanic, or carbonate rock and a number of micrite envelopes (Fig. 4F). Micrite envelopes are orange-brown in colour and in some cases show some birefringence, indicating the presence of clays. The ooids range in size from $0.08 \mathrm{~mm}$ to $4 \mathrm{~mm}$ across.
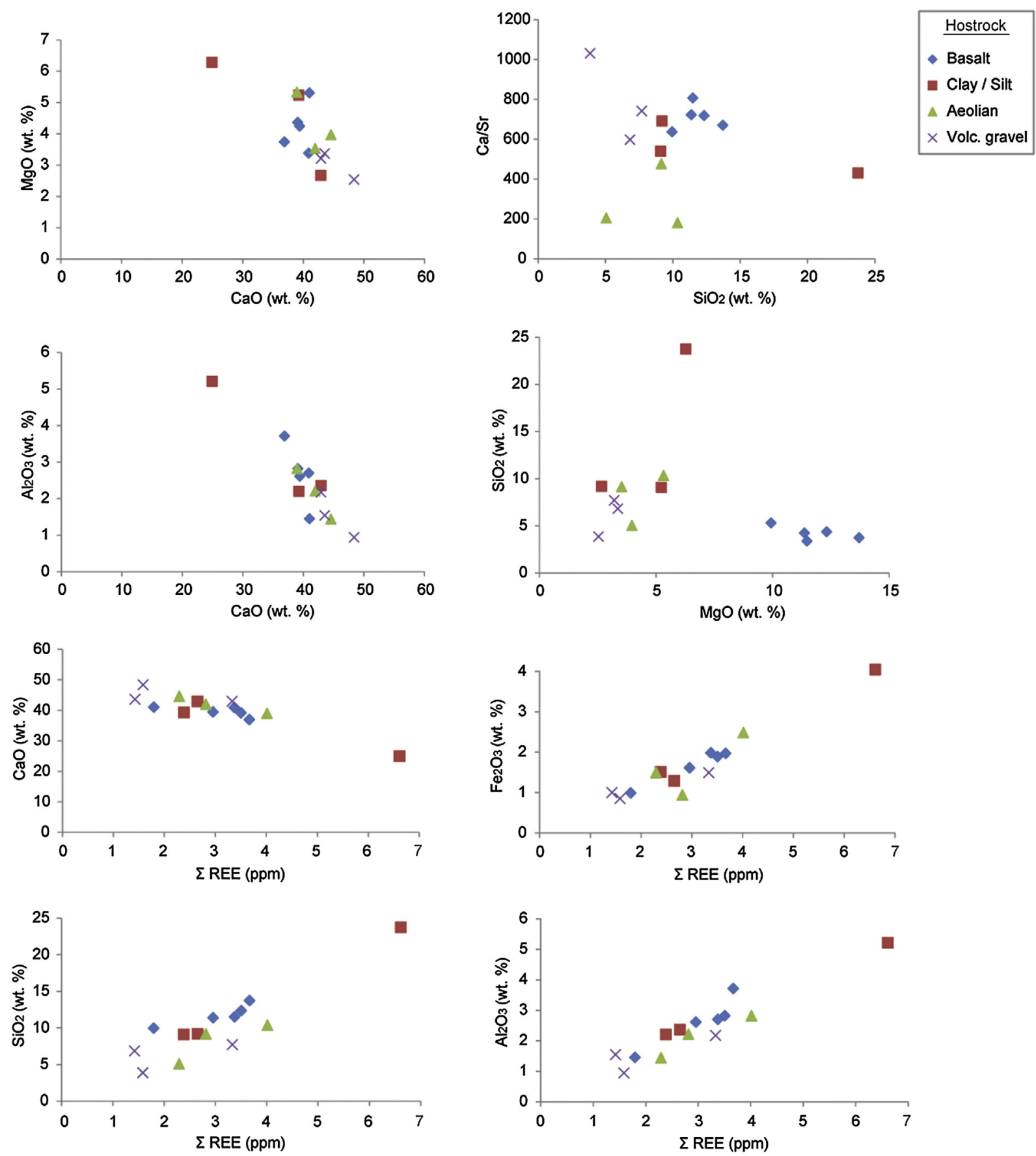

Fig. 5. Binary diagrams of major, minor and total rare earth elements for calcretes are grouped according to the host rocks on which they are developed. 


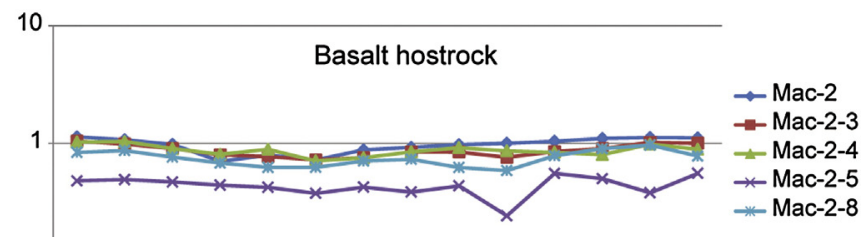

0,1

La $\mathrm{Ce} \mathrm{Pr}$ Nd $\mathrm{Sm} \mathrm{Eu}$ Gd Tb Dy Ho Er Tm Yb Lu
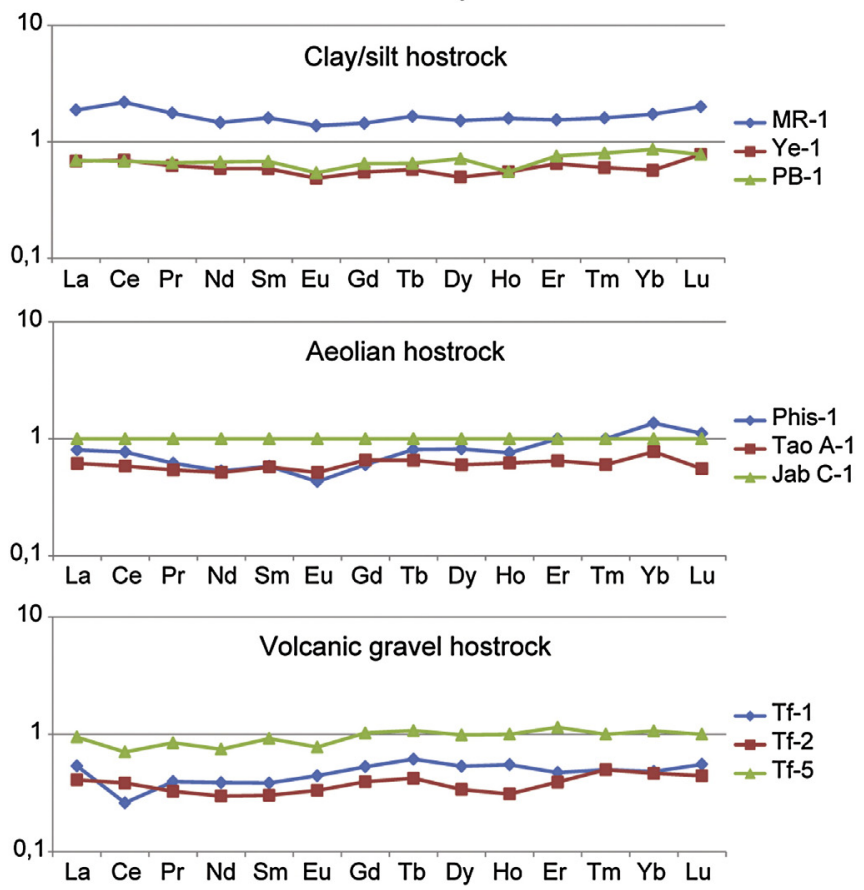

Fig. 6. JAB-C-1 normalized rare earth element plots for the various host rocks.

\section{Mineralogy}

Main mineral phases present in these deposits are calcite and phyllosilicates, followed by feldspars (K-feldspar and plagioclases), aragonite, and clinopyroxene (Table 1 ). Quartz is considered a major component because of its significance in this setting, although it can appear in variable proportions, sometimes lower than 5\%. Error in these estimations is $\pm 3 \%$. Trace phases $(<5 \%)$ also detected are dolomite, ankerite, kutnahorite, epsomite, gypsum, foids, Feoxides/hydroxides. Their low contents make not possible the quantification of such mineral phases; however, they are clearly identifiable in some difractograms.

Relationships between the major mineral phases were analyzed. Samples with anomalous content of aragonite and/or clynopiroxene were omitted. There is a strong negative correlation between calcite and feldspars plus phyllosilicates $\left(\mathrm{R}^{2}=0.9569\right)$. There are good negative correlations between calcite and phyllosilicates $\left(R^{2}=0.7731\right)$ and between calcite and tectosilicates (quartz + feldspar) $\left(\mathrm{R}^{2}=\right.$ $0.7252)$. Positive but a low covariation trend $\left(R^{2}=0.4566\right)$ was found for quartz and phyllosilicates. There is no correlation between feldspars and phyllosilicates $\left(R^{2}=0.0086\right)$, nor between quartz and feldspars $\left(\mathrm{R}^{2}=0.0346\right)$.

\section{Geochemistry and isotope geochemistry}

\subsection{Major, trace and REE}

In samples contents of $\mathrm{SiO}_{2}$ (3.85-23.75\%), $\mathrm{Al}_{2} \mathrm{O}_{3}$ (0.94-5.21\%), $\mathrm{Fe}_{2} \mathrm{O}_{3}$ (0.85-4.04\%), $\mathrm{CaO}$ (24.93-48.37\%) and $\mathrm{MgO}(2.54-6.28 \%)$ are variable. The amount of $\mathrm{MgO}, \mathrm{Fe}_{2} \mathrm{O}_{3}, \mathrm{SiO}_{2}$ and $\mathrm{Al}_{2} \mathrm{O}_{3}$ increases as $\mathrm{CaO}$ decreases (Fig. 5). In the samples with aeolian host rock rather than clay and basalt host rocks the $\mathrm{Ca} / \mathrm{Sr}$ ratio is lower.

The correlation between oxide contents and REE content shows that the more $\mathrm{Fe}_{2} \mathrm{O}_{3}, \mathrm{SiO}_{2}$ and $\mathrm{Al}_{2} \mathrm{O}_{3}$ in the sample, the greater the content of $\mathrm{REE}$, while $\mathrm{CaO}$ content is constant in samples analyzed while REE content does not follow any pattern.

Results of REE were normalized using the sample JAB C- 1 of this study, the standard aeolian sample. No positive or negative anomalies are present in the REE diagrams (Fig. 6). In general most of the calcretes are impoverished in REE with respect to the aeolian standard, except one sample from host rock dominated micro-fabric developed over a clay-rich host rock.

The Sc-Th-Ta and Co-Hf-Th compositions were plotted on the ternary diagram from Muhs et al. (2010) from which the compositional fields of the two possible source materials (African dust and basalt from Lanzarote) can be inferred. The Sc-Th-Ta composition of the samples either scatters between the two source materials, or falls directly in their fields. In the case of $\mathrm{Co}-\mathrm{Hf}-\mathrm{Th}$ composition, distribution again spans the range defined by the source materials, but is more homogeneous (Fig. 7).
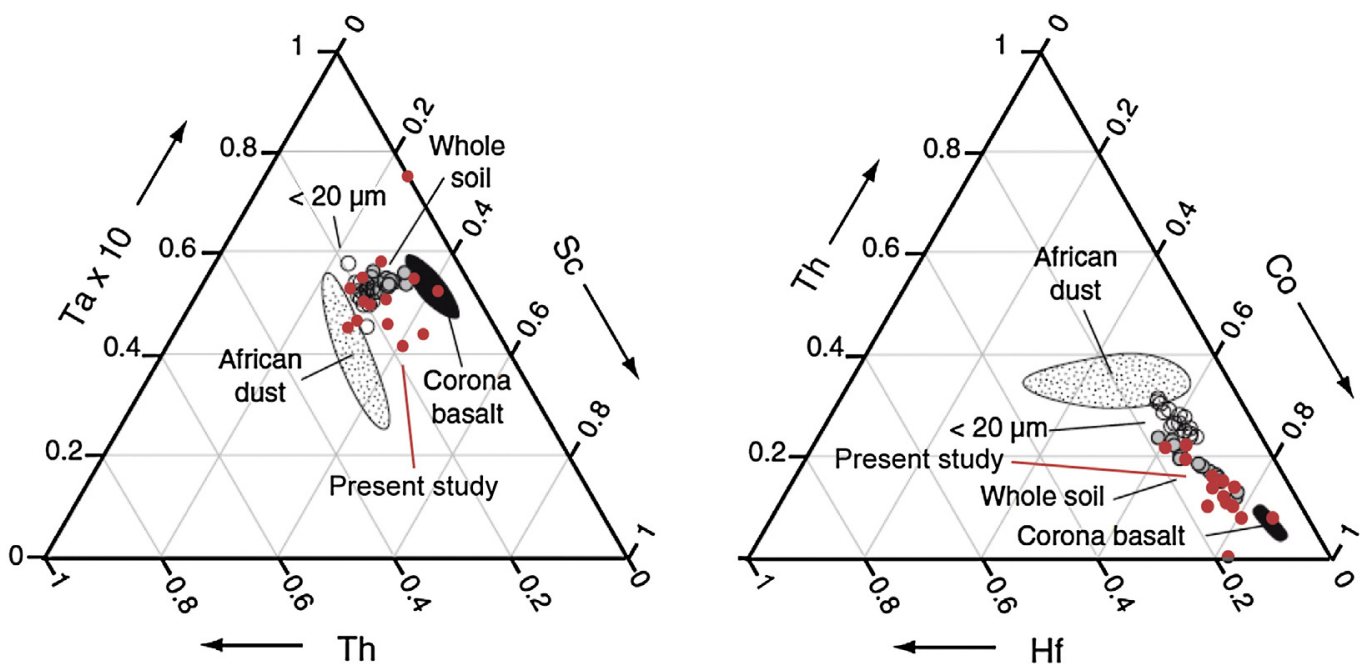

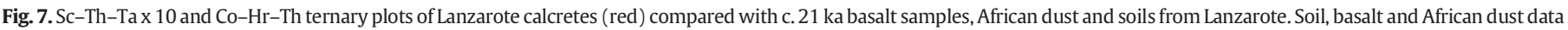

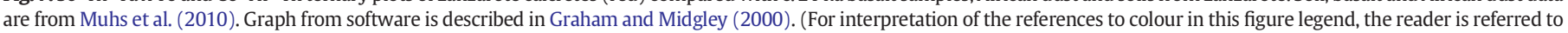
the web version of this article.) 


\section{2. ${ }^{87} \mathrm{Sr} /{ }^{86} \mathrm{Sr}$ isotope geochemistry}

Carbonate from the calcrete samples has ${ }^{87} \mathrm{Sr} /{ }^{86} \mathrm{Sr}$ ratios between 0.706357 and 0.709208 . In contrast the basalt sample analyzed has a lower value of 0.703317 .

Calcretes formed on basaltic host rocks have values that range from 0.707606 to 0.708593 and vary less than those of calcretes developed in basaltic gravels (0.706908-0.708567) (Fig. 8). The clay-silt host rocks come from the weathering of volcanic rocks or by loess deposition. The values for the calcretes formed on clay-silt host rocks range from 0.707173 to 0.708861 . The mean ${ }^{87} \mathrm{Sr} /{ }^{86} \mathrm{Sr}$ value for these calcretes is higher than the mean of calcretes from basaltic or basaltic gravel host rocks (Fig. 8). Calcretes developed on the aeolian host rocks have higher ${ }^{87} \mathrm{Sr} /{ }^{86} \mathrm{Sr}$ values $(0.708949$ to 0.709224$)$, very close to the sea water value (Fig. 8).

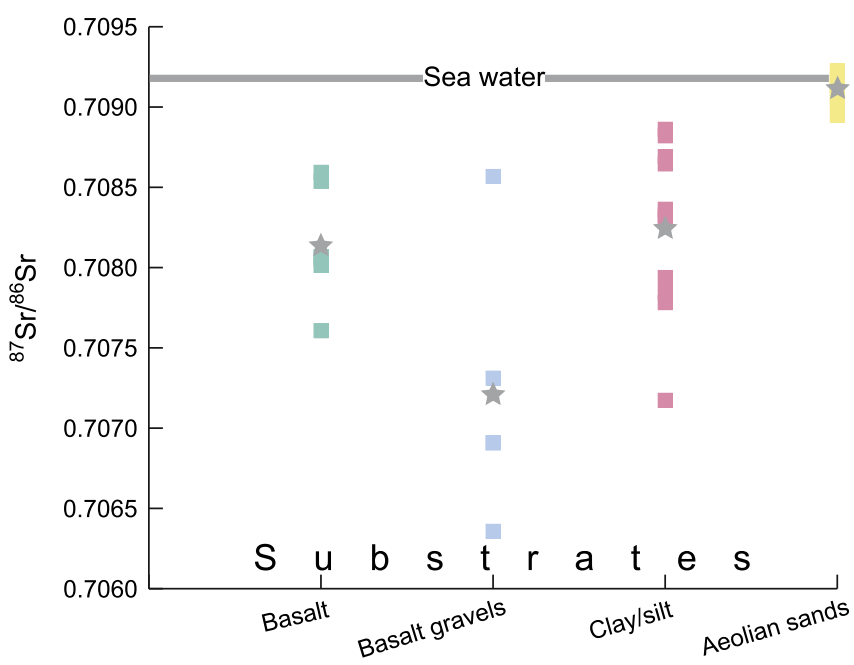

Fig. 8. ${ }^{87} \mathrm{Sr} /{ }^{86} \mathrm{Sr}$ ratios for calcretes developed on different host rocks. Present-day sea water also plotted. For more details see Table 1.

Table 2

Temperatures and $\Delta^{18} \mathrm{O}$ calculated values for Eastern Canary Islands and Guadix Basin (Iberian Peninsula) $\left(\Delta^{18} \mathrm{O}=\delta{ }^{18} \mathrm{O}\right.$ calcite $-\delta^{18} \mathrm{O}_{\text {rainwater }}$ ); equilibrium temperature $\left({ }^{\circ} \mathrm{C}\right) \mathrm{cal}$ culated using the $10^{3} \mathrm{Ln} \alpha_{\text {calcite-water }}$ equilibrium equation from Kim and O'Neil (1997); disequilibrium temperature $\left({ }^{\circ} \mathrm{C}\right)$ calculated using the $10^{3} \mathrm{Ln} \alpha_{\text {bicarbonate-water }}$ equilibrium equation and Hałas and Wołacewicz (1982).

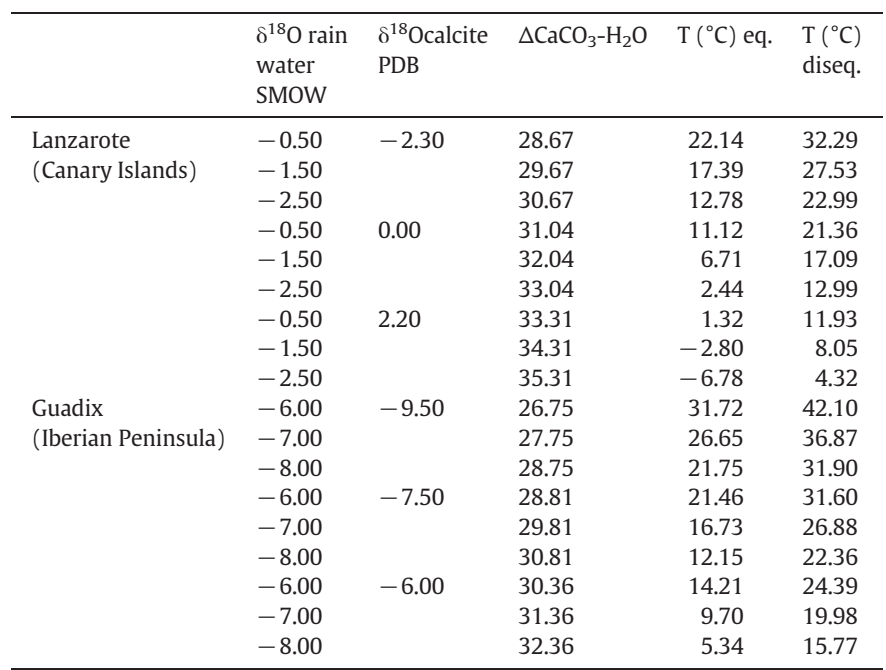

\subsection{Stable isotopes}

Carbon isotope values vary between +0.24 and $-8.21 \%$ VPDB, and oxygen between -2.70 and $+2.22 \%$ 。PDB (Table 2 ). Heavier values are found in calcretes developed in aeolian deposits that contain a large amount of marine bioclasts (Fig. 9). Apart from the calcretes developed in the aeolian deposits the other sets of samples do not differ significantly. Overall values show a low covariance between $\delta^{18} \mathrm{O}$ and $\delta^{13} \mathrm{C}$. If samples from aeolian/marine substrates are not considered, then the covariance trend is relatively good.

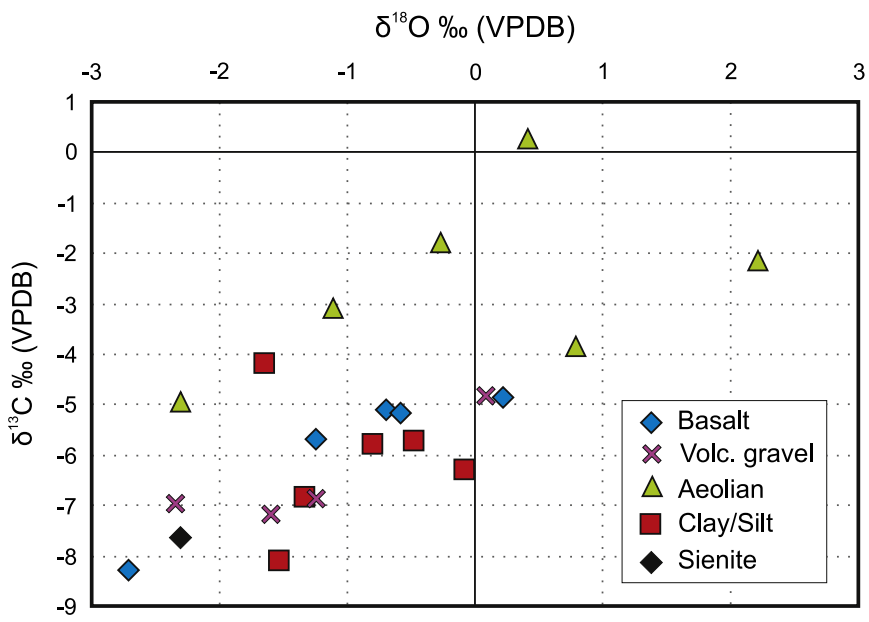

Fig. 9. $\delta^{18} \mathrm{O}_{\text {VPDB }}$ and $\delta^{13} \mathrm{C}_{\text {VPDB }}$ plots of Lanzarote and Fuerteventura calcretes. The host rock of calcretes is represented. For more details see Table 1.

\section{Discussion}

\subsection{Calcrete formation model}

The characteristic of both calcrete profiles and micro-fabrics indicates that calcretes were formed by pedogenic processes in a vadose environment, with little influence of groundwater. This can be inferred from: a) the decrease downward in the amount of carbonate in the host rockdominated micro-fabrics, b) the isotope composition and c) the absence of a shallow groundwater table in the present-day volcanic slopes. For example, in Macher profile the number and size of carbonate-filled cracks clearly decrease from the boundary between the cracked basalt and the laminar calcrete. This indicates a lack of shallow groundwater bodies and also that most of the carbonate percolated into the profiles "perdescensum" (Goudie, 1983) (Fig. 10). The morphology and distribution of micritic coatings within aeolian sands are also characteristic of vadose environments. The lack of well-cemented horizons below them is also evidence of percolating meteoric waters. The pervasive insect trace fossils in these profiles, in cases coated by micrite envelopes (Genise et al., 2013), also indicate that these calcretes formed in sub-aerial vadose settings. As well as the laminar calcrete dipping downslope more than surface slope what suggest that the plant root system extended within the soil following the infiltration trajectories of the vadose waters. Calcrete formation was driven by the activity of plants and invertebrate animals. In the initial stages of calcrete development roots, soil fauna and associated microbes colonizing host rocks induced carbonate precipitation (Genise et al., 2013), mostly in thin irregular laminae, carbonate coatings, peloids and nodules (Fig. 10). At the top of profiles, calcrete dominated microfabrics form horizons of thick carbonate precipitation in which various calcrete micro-fabrics interbed (laminar, granular or sandy micrite) with thin red mudstones. These mm-scale irregular interbeddings have been interpreted as the result of short-term periods of sedimentation followed by periods of calcrete formation (Fedoroff et al., 1994), with the aeolian and alluvial sedimentation (red mudstones) occurring in 

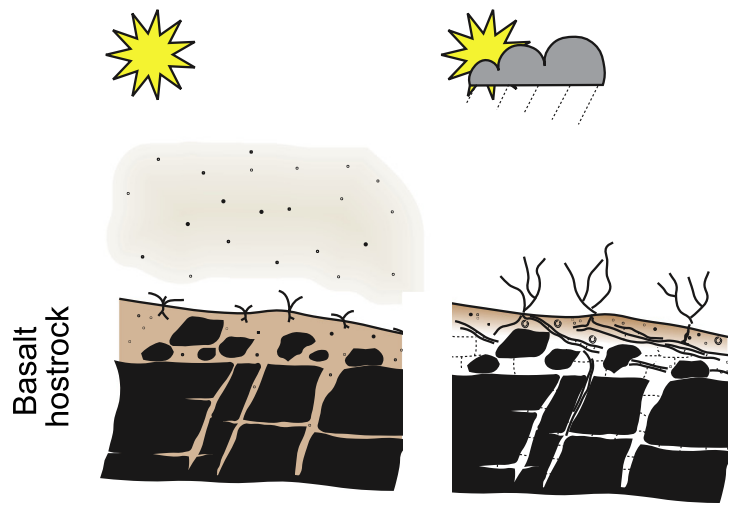

Aeolian dust deposition on substrate or weathered substrate

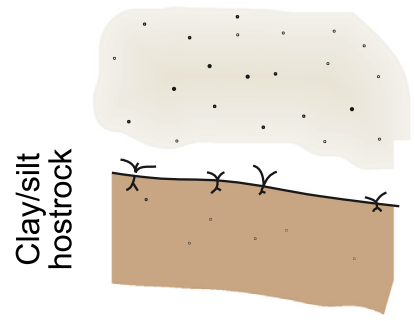

Dust carbonate leaching and precipitation in lower horizons

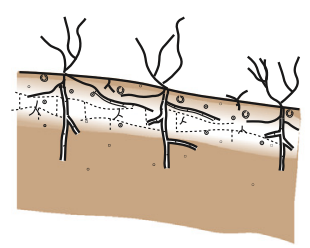

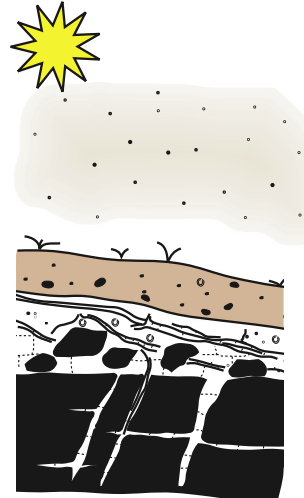

Sedimentation (aeolian/aluvial) and cementation of lower horizons

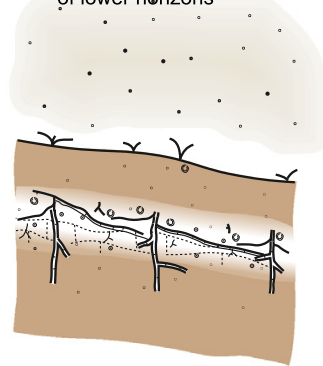

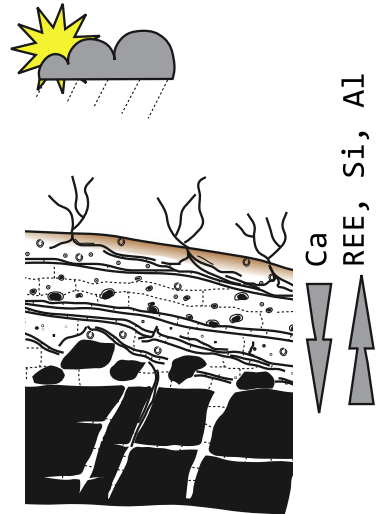

Aggradation of the profile by carbonate particles deposition, leaching and precipitation, \&

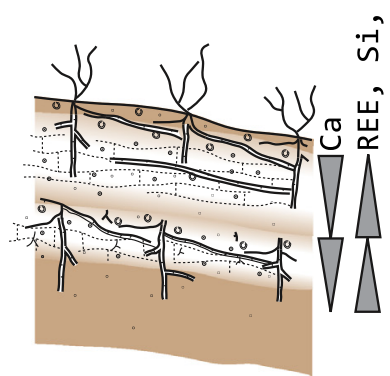

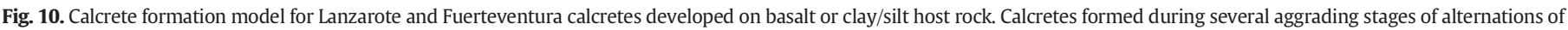
aeolian dust deposition during dry periods with leaching and calcite precipitation during wetter periods. Legend in Fig. 2 .

more arid periods with sparse vegetation, while the calcretes were developed in relatively less arid periods (Alonso-Zarza and Silva, 2002; Meléndez et al., 2011) (Fig. 10). Thicker $\mathrm{dm}$ to $\mathrm{m}$ cycles would represent long-scale climatic changes (Alonso-Zarza and Silva, 2002). Thus these calcretes are formed by vertical aggradation of successive calcretedominated micro-fabrics to the top of profiles (Fig. 10). Previous studies carried out on calcretes and palaeosols of Eastern Canary Islands agree that calcrete profiles were developed in relatively wetter periods of an arid to semi-arid climate (Damnati, 1997; Meco, 2008). This is in agreement with Candy et al. (2012) and with the age of some interglacial calcrete profiles from Lanzarote and Fuerteventura which can be dated by correlation with marine terraces, sand dunes, lava flows, and loess deposits. Femés calcrete profile developed on loess deposits mainly around 100 ka BP during OIS-5 (von Suchodoletz et al., 2010) as well as other calcrete profile, not described here, in El Berrugo (Lanzarote) which correlates with coastal deposits from this period with Senegalese fauna (Zazo et al., 2002). On the contrary the Jable de Tao calcrete profile developed on sand dunes which could be more recent about $12 \mathrm{ka}$ (Ortiz et al., 2006) although some ages from this paper are considered younger than what they really are (von Suchodoletz et al., 2012). In Fuerteventura, calcretes preserved in talus flatirons developed around 30 and $50 \mathrm{ka}$ (Gutiérrez-Elorza et al., 2013). The gully incision that dissects the calcrete profiles occurred during the last glaciation what indicates that the main calcrete formation period finished at this time. Assessing the exact time of calcrete formation is very complex by several reasons: 1) Laminar calcrete formation is a multiepisodic processes that take place along long periods of time, for example in the Ebro Basin thick laminar calcretes similar to the studied here may have been forming during 1 My (Meléndez et al., 2011), 2) They are not pure calcium carbonate and so the geochemical data used for dating can show contamination of the host rock giving so incorrect results.

\subsection{Climatic conditions}

The Canarian calcretes were formed mainly during the humid and warm stages of an arid to semiarid climate during Middle and Late Pleistocene but those formed initially during Middle Pleistocene could have continued forming during earlier times. Those calcretes formed during OIS- 5 developed under humid and warm conditions as is suggested by the presence of Senegalese fauna in the marine deposits (Zazo et al., 1997, 2002), the existence of lateritic soils associated with weathered pyroclasts in Teno (Tenerife) (Meco, 2008), and the intense presence of insect trace fossils, and root traces in the calcretes (Meco et al., 2011; Genise et al., 2013).

$\delta^{18} \mathrm{O}$ values of samples studied are heavier (about 3\%) than those commonly found in calcretes from Europe (Alonso-Zarza and Arenas, 2004; Candy et al., 2012) or Asia (Khadkikar et al., 2000). As indicated previously, most calcrete features are pedogenic, with little contribution from groundwater processes. This suggests that $\delta^{18} \mathrm{O}$ values of calcretes reflect heavier values of rain water in eastern Canary Islands (Yanes et al., 2008), in comparison with that of Europe and India, due to the higher temperature prevailing in the Canary Islands.

$\delta^{18} \mathrm{O}$ values of Canarian calcretes have been compared with those obtained in similar Pleistocene laminar calcretes from Guadix Basin (SE Iberian Peninsula, Spain) (Azañón et al., 2006) in order to calculate the possible prevailing temperatures in both settings. $\delta^{18} \mathrm{O}$ values of rainwater from Guadix vary from -8 to $-6 \%$ SMOW (near 1000 masl) (Vallejos et al., 1997), whereas eastern Canary Islands values vary between -0.5 and $-2.5 \%$ SMOW (Yanes et al., 2008). These data were used to calculate $\Delta^{18} \mathrm{O}\left(=\delta^{18} \mathrm{O}_{\text {calcite }}-\delta^{18} \mathrm{O}_{\text {rainwater }} \approx 10^{3} \ln \alpha\right)$ (Table 2$)$. Temperature range was estimated using the Kim and O'Neil (1997) oxygen isotope fractionation equation between calcite and water under equilibrium, whereas Hałas and Wołacewicz (1982) equation was used for disequilibrium conditions (McCrea, 1950). We used temperature 
range of 15 to $25^{\circ} \mathrm{C}$ (Yanes et al., 2008) for the Canary Islands and obtained $\Delta^{18} \mathrm{O}$ values ranging from 28.4 to 30.2 (under equilibrium) and from 30.2 to 32.6 (under disequilibrium). For the same temperature range, $\Delta^{18} \mathrm{O}$ values for the Guadix calcretes vary from 28.1 to 30.2 (under equilibrium) and from 30.2 to 32.4 (under disequilibrium) (Fig. 11).

Lines obtained under disequilibrium from the Guadix and Canarian calcretes are not parallel and cut at about $24{ }^{\circ} \mathrm{C}$. The Guadix lines have a higher slope (Fig. 11). This indicates that for a given range of fractionation the corresponding temperature range is narrower in the Canary calcretes, which fits well with present climatic conditions in the two areas; more constant temperatures in the Canaries are due to their latitude, altitude and the influence of the Atlantic Ocean.

The $\delta^{13} \mathrm{C}$ are in the average range of pedogenic calcretes (Talma and Netterberg, 1983; Sinha et al., 2006). Variations in $\delta^{13} \mathrm{C}$ in calcretes formed in similar palaeogeographic settings seem to be controlled by both variations in relative amounts of $C_{3}$ versus $C_{4}+$ CAM plants and by density of vegetation (Quade et al., 1989; Tanner, 2010). At present the eastern Canary Islands support the three types of plants (Yanes et al., 2008), so very probably the calcretes studied formed under the influence of $C_{3}, C_{4}$ and CAM plants. Lighter $\delta^{13} \mathrm{C}$ values such as those found in the Himalayas would be indicative of soils developed in more humid settings dominated by $C_{3}$-plants (Srivastava and Sauer, 2014). On the contrary, heavier ones would be more characteristics of $\mathrm{C}_{4}+$ CAM plants inhabiting warmer and more arid areas, such as the Canary Islands.

Covariant trend between $\delta^{18} \mathrm{O}$ and $\delta^{13} \mathrm{C}$ is relatively low $\left(\mathrm{R}^{2}=0.38\right)$ if all samples are considered. However, $\mathrm{R}^{2}$ reaches a value of 0.68 if only basalt-related substrates are considered. As geochemistry suggests substrate did not exert a strong control over calcrete formation, other controls may be invoked to explain such differences. The colonization of different plant species ( $\mathrm{C} 3$ or C4) may be controlled by the substrate, being different in carbonate-dominated (aeolian/marine) than in basalt-related substrates. This could have produced a distinct utilisation of $\mathrm{C}$ depending on the plant metabolism ( $\mathrm{C} 3$ or $\mathrm{C} 4$ ) (Blagodatskaya et al., 2011). The covariant trend between $\delta^{18} \mathrm{O}$ and $\delta^{13} \mathrm{C}\left(\mathrm{R}^{2}=0.68\right.$, considering the same species of plants) indicates that both variables responded to the same environmental control. Similarly to what occurs in Quaternary soils of the Mediterranean area (Candy et al., 2012), covariance may be controlled by climate. More arid conditions would result in reduced vegetation cover, domination of $\mathrm{C}_{4}+$ CAM plants and so higher $\delta^{13} \mathrm{C}$ and $\delta^{18} \mathrm{O}$ ratios.

\subsection{Source of calcium other major elements and $\mathrm{CO}_{2}$}

\subsubsection{Host rock}

Variation in amounts of the different elements is due to: differences in host rocks on which profiles developed; presence of detrital and volcanic material in samples; and degree of calcrete development. The content of $\mathrm{Al}_{2} \mathrm{O}_{3}, \mathrm{FeO}_{2}$ and $\mathrm{SiO}_{2}$ in the studied calcretes is sourced from feldspars, phyllosilicates and pyroxenes of host rock, as can be deduced from samples having larger amounts of those minerals (Fig. 5).

REE correlates well with $\mathrm{Fe}_{2} \mathrm{O}_{3}, \mathrm{SiO}_{2}$ and $\mathrm{Al}_{2} \mathrm{O}_{3}$, indicating that their sources are the host rock. Only weak negative correlation between $\mathrm{CaO}$ and REE was found. Distribution of REE in calcretes is similar to that of whole soils studied by Muhs et al. (2010), with a composition intermediate between aeolian dust and basalt. The REE differences of calcretes with higher pedogenic carbonate content from the standard REE distribution is an indication that REE are sourced either from host rock or from aeolian dust. Within each profile (i.e. Macher or Tefia) depletion in REE does not trend upward as could be expected; on the contrary REE contents are higher in the horizons containing less carbonate and more silt, supporting multi-episodic aeolian input during stages of calcrete development.

Pedogenic carbonate should record the strontium signal from different sources, both the external dust input and the in situ weathering sources that contribute to soil formation (Capo et al., 1998; Van der Hoven and Quade, 2002).

The ${ }^{87} \mathrm{Sr} /{ }^{86} \mathrm{Sr}$ ratios of calcretes developed on basalts differs notably from those of basalt samples analyzed, suggesting that basaltic host rock did not supply much $\mathrm{Sr}$ (Ca) to the calcretes, as observed in other studies in which calcretes developed on volcanic or plutonic host rocks (Chiquet et al., 1999; Hamidi et al., 1999; Hamidi et al., 2001). On the contrary, the ${ }^{87} \mathrm{Sr} /{ }^{86} \mathrm{Sr}$ ratio is indicative of an important external source of $\mathrm{Sr}$ within the soluble fraction of aeolian dust. This external vs in situ source of $\mathrm{Sr}(\mathrm{Ca})$ has also been reported in New Mexico (Capo and Chadwick, 1999) where the $\mathrm{Sr}$ isotopic values are quite similar to those found in our study.

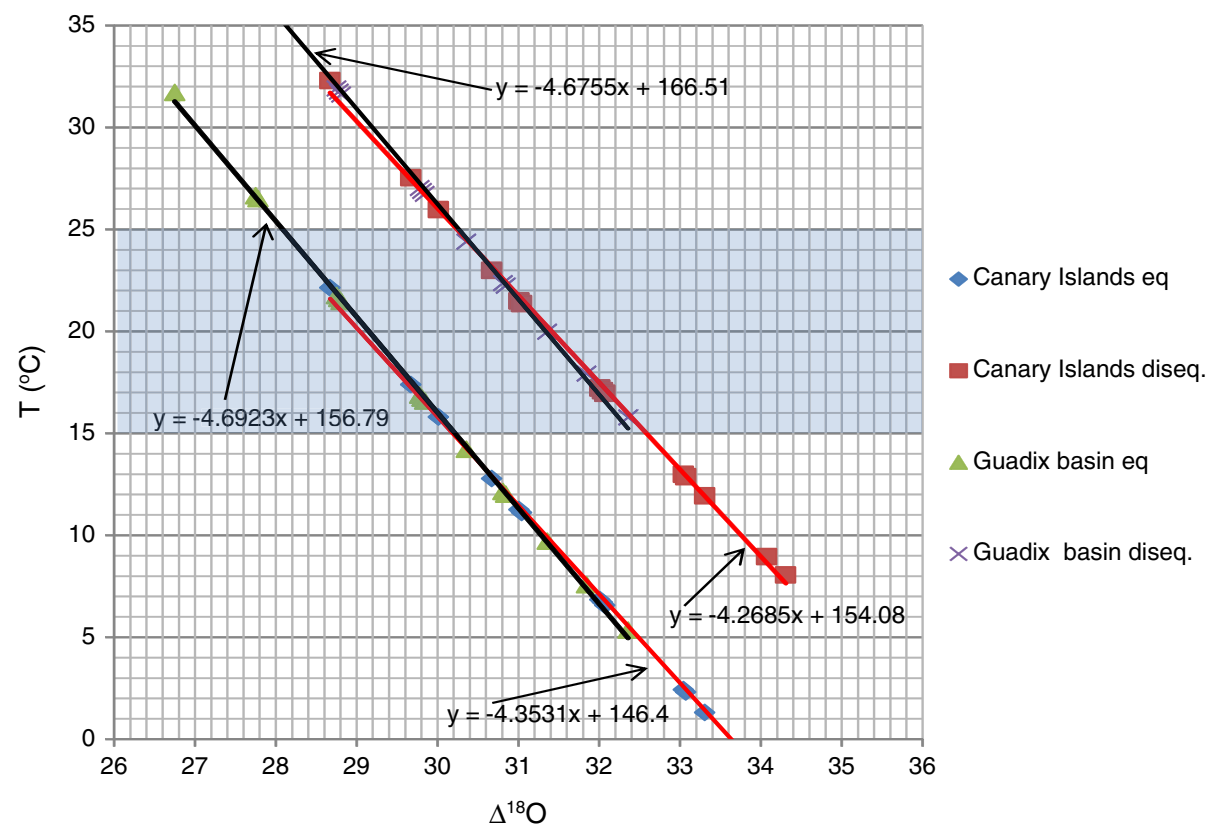

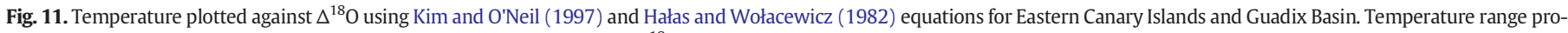

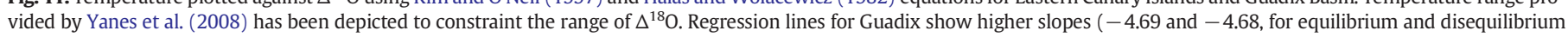
respectively) than those for Eastern Canary Islands ( -4.35 and -4.27 , for equilibrium and disequilibrium, respectively). 
The mean of ${ }^{87} \mathrm{Sr} /{ }^{86} \mathrm{Sr}$ values for calcretes developed on clay-silt host rocks is only slightly higher than the mean of calcretes developed on basalt or basalt gravel host rocks, indicating that most calcretes developed on Lanzarote and Fuerteventura Islands have an external common source of calcium independent of the host rock, except for calcretes developed on marine bioclastic host rocks (aeolian sand-sheets or dunes) or affected by sea-spray (see discussion below). The external source of $\mathrm{Ca}(\mathrm{Sr})$ is very probably aeolian dust transported from the Sahara and Sahel areas (Muhs et al., 2010) as is evidenced by the Sr isotopes of loess deposits. Supply of calcite particles from aeolian dust has been documented by several authors (Coudé-Gaussen et al., 1987; Coudé-Gaussen and Rognon, 1988; Grousset et al., 1992; Criado and Dorta, 2003; Khiri et al., 2004; Menéndez et al., 2007; Criado et al., 2011; Scheuvens et al., 2013). The ${ }^{87} \mathrm{Sr} /{ }^{86} \mathrm{Sr}$ values are quite similar to those of the Jurassic limestones from the Atlas region (Hamidi et al., 2001), although other areas with Mesozoic carbonates could be contributing calcite to Lanzarote and Fuerteventura calcretes (Muhs et al., 2010). In addition, the presence of quartz in most of the samples (up to $21 \%$ in Femés and 14\% in Mirador del Río profiles) also indicates external inputs of material, as there is no source of quartz in the islands. The most probable sources are aeolian plumes from North Africa (Mizota and Matsuhisa, 1995; Muhs et al., 2010) referred above.

Calcretes developed on aeolian sand host rock may have both internal and external Ca sources as indicated by the highest Sr ratios very similar to sea water values. Ca can derive from sea spray, from an aeolian source of marine calcite (Herut et al., 1993; Rognon and Coudé-Gaussen, 1996; Hamidi et al., 1999), or from internal aeolian sand deposits such El Jable sands. These sands contain marine carbonate bioclasts sourced from the nearby beach.

\subsection{2. $\mathrm{CO}_{2}$}

There are three possible sources of $\mathrm{CO}_{2}$ for calcrete formation: soil, weathering and volcanic $\mathrm{CO}_{2}$. Calculation of the original signal of $\delta^{13} \mathrm{C}$ from $\mathrm{CO}_{2}(\mathrm{~g})$ can help to decipher the $\mathrm{CO}_{2}$ sources. We have done tentative calculations using the average temperature range $15-25{ }^{\circ} \mathrm{C}$ (Yanes et al., 2008), combined with ${ }^{13} \mathrm{C}$ fractionation equations from Zhang et al. (1995) (fractionation at equilibrium conditions), and Mook et al. (1974) (fractionation under disequilibrium conditions). The $\delta^{13} \mathrm{C}$ obtained values for the original $\mathrm{CO}_{2}$ (gas) range between -14 and $-6 \%$ VPDB under equilibrium conditions (Zhang et al., $1995)$, and between -17.7 and $-7.6 \%$ VPDB if fractionation under disequilibrium is considered (Mook et al., 1974) (Fig. 12). Our results fit well with the values of soil $\mathrm{CO}_{2}$ of the Canary Islands indicating that
$\mathrm{CO}_{2}$ fixed in calcretes originated mostly in soil with very little contribution from weathering or volcanic $\mathrm{CO}_{2}$ (Fig. 12). This also supports the common idea that calcretes are not important sinks of $\mathrm{CO}_{2}$ sourced either from weathering (Dart et al., 2007; Liu, 2011) or released from volcanic gases.

\section{Conclusions}

The eastern Canary Islands are characterized by a large amount of Pleistocene calcretes developed mainly on volcanic rocks, but also in sand dunes and clay-silt deposits as well. The combination of field, petrological and geochemical data suggest that Canary Island calcretes developed in several aggrading stages. Dust and/or alluvial deposition during arid periods alternated with carbonate leaching and precipitation during more humid stages where plants, insects and bacteria played a role in calcrete formation.

Stable $\mathrm{O}$ and $\mathrm{C}$ isotopes indicate that calcretes were formed by pedogenic processes within a vadose environment with little contribution from groundwater. The $\delta^{13} \mathrm{C}$ values originated from soils with different proportions and densities of C3, C4 and CAM plants, as occurs nowadays in the eastern Canary Islands. Most $\mathrm{CO}_{2}$ was of pedogenic origin. Aeolian dust was the main source of $\mathrm{Ca}$ for the formation of these calcretes, whereas Ca coming from the weathering of volcanic host rock contributed very little to calcrete formation, as is evidenced by ${ }^{87} \mathrm{Sr} /{ }^{86} \mathrm{Sr}$, and some REE ratios.

The aggradational calcrete formation model proposed for these calcretes supports the idea that the carbonate source was mostly aeolian dust carried by the Saharan and Sahel winds during the relatively more arid periods. This model, together with the determination of the $\mathrm{Ca}$ source, leads to predictions of the palaeoclimatic conditions prevailing in the islands during Pleistocene, which correspond to observed calcrete features. Our results stress that Ca-rich host rocks were not a prerequisite for calcrete formation and so in these cases calcretes are not significant sinks for the $\mathrm{CO}_{2}$ produced by the weathering of the host rock or by volcanic processes.

\section{Acknowledgements}

This research was funded by Project CGL-2011-27826-C02-01 from MINECO. We thank A. Meléndez and J. Genise for collaboration in previous field work studies and J. Cerne for English revision. We also thank the editor Thierry Corrège, Ofelia Tófalo and an anonymous reviewer for their comments on a previous version of the manuscript.

\section{KEY}

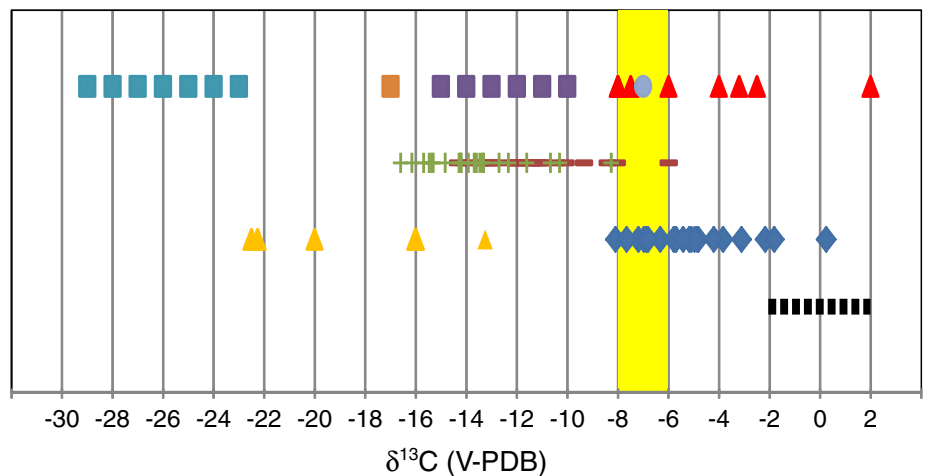

$\Delta$ Volcanic $\mathrm{CO}_{2}$ (Custodio et al., 1987)

$\triangle$ Soil CO2 (Gran Canaria) (Gasparini et al., 1990)

- C3 plants

- C4 plants

- CAM plants

- Pre-Industrial atmosphere

- Eastern Canary Islands (this work)

- Calculated $\mathrm{CO}_{2}$ (g) eq.

+ Calculated $\mathrm{CO}_{2}(\mathrm{~g})$ diseq.

III Typical marine calcite signal

$\delta^{13} \mathrm{C}(\mathrm{V}-\mathrm{PDB})$

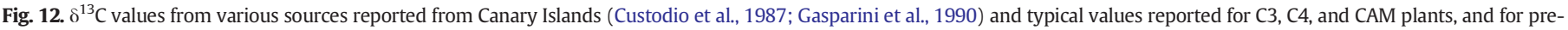

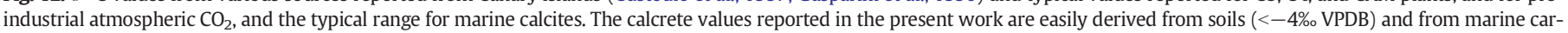
bonates $\left(>-4 \%\right.$ ). The calculated values for $\mathrm{CO}_{2}$ (gas) fit very well to those from soil origin. 


\section{References}

Alonso-Zarza, A.M., Arenas, C., 2004. Cenozoic calcretes from the Teruel Graben, Spain: microstructure, stable isotope geochemistry and environmental significance. Sediment. Geol. 167 (1-2), 91-108.

Alonso-Zarza, A.M., Silva, P.G., 2002. Quaternary laminar calcretes with bee nests: evidences of small-scale climatic fluctuations, Eastern Canary Islands, Spain. Palaeogeogr. Palaeoclimatol. Palaeoecol. 178 (1-2), 119-135.

Alonso-Zarza, A.M., Wright, V.P., 2010. Chapter 5. Calcretes. In: Alonso-Zarza, A.M., Tanner, L.H. (Eds.), Carbonates in Continental Settings: Facies, Environments, and ProcessesDevelopments in Sedimentology. Elsevier, Amsterdam, pp. 226-267.

Ancochea, E., Barrera, J.L., Bellido, F., Benito, R., Brändle, J.L., Cebriá, J.M., Coello, J., Cubas, C.R., De La Nuez, J., Doblas, M., Gómez, J.A., Hernán, F., Herrera, R., Huertas, J.M. López Ruiz, J., Martí, J., Muñoz, M., Sagredo, J., 2004. Canarias y el Vulcanismo Neógeno penínsular. In: Vera, J.A. (Ed.), Geología de España. SGE-IGME, Madrid, pp. 635-682

Azañón, J.M., Tuccimei, P., Azor, A., Sánchez-Almazo, I.M., Alonso-Zarza, A.M., Soligo, M., Pérez-Peña, J.V., 2006. Calcrete features and age estimates from U/Th dating: implications for the analysis of Quaternary erosion rates in the northern limb of the Sierra Nevada range (Betic Cordillera, southeast Spain). In: Alonso-Zarza, A.M., Tanner, L.H. (Eds.), Paleoenvironmental Record and Applications of Calcretes and Palustrine CarbonatesGeological Society of America Special Paper. The Geological Society of America Boulder, Colorado, pp. 223-239.

Balcells Herrera, R., Barrera Morate, J.L., Gómez Sainz de Aja, J.A., Ancochea Soto, E. and Cueto Pascual, L.A., 2006. Mapa Geológico de España 1:100.000. Isla de Fuerteventura. Hoja N ${ }^{\circ} 92$ Mapa Geologico de España. IGME, Madrid.

Blagodatskaya, E., Yuyukina, T., Blagodatsky, S., Kuzyakov, Y., 2011. Turnover of soil organic matter and of microbial biomass under $\mathrm{C}_{3}-\mathrm{C}_{4}$ vegetation change: consideration of ${ }^{13} \mathrm{C}$ fractionation and preferential substrate utilization. Soil Biol. Biogeochemistry 43, 159-166.

Bozzano, G., Kuhlmann, H., Alonso, B., 2002. Storminess control over African dust input to the Moroccan Atlantic margin (NW Africa) at the time of maxima boreal summer insolation: a record of the last $220 \mathrm{kyr}$. Palaeogeogr. Palaeoclimatol. Palaeoecol. 183, 155-168.

Cailleau, G., Braissant, O., Verrecchia, E.P., 2004. Biomineralization in plants as a long-term carbon sink. Naturwissenschaften 91 (4), 191-194.

Candy, I., Adamson, K., Gallant, C.E., Whitfield, E., Pope, R., 2012. Oxygen and carbon isotopic composition of Quaternary meteoric carbonates from western and southern Europe: their role in palaeoenvironmental reconstruction. Palaeogeogr. Palaeoclimatol. Palaeoecol. 326-328, 1-11.

Capo, R.C., Chadwick, O.A., 1999. Sources of strontium and calcium in desert soil and calcrete. Earth Planet. Sci. Lett. 170 (1-2), 61-72.

Capo, R.C., Stewart, B.W., Chadwick, O.A., 1998. Strontium isotopes as tracers of ecosystem processes: theory and methods. Geoderma 82, 197-225.

Carracedo, J.C., Day, S., Guillou, H., Rodríguez Badiola, E., Canas, J.A., Pérez Torrado, F.J., 1998. Hotspot volcanism close to a passive continental margin: the Canary Islands. Geol. Mag. 135 (5), 591-604.

Carracedo, J.C., Pérez Torrado, F.J., Ancochea, E., Meco, J., Hernán, F., Cubas, C.R., Casillas, R., Rodríguez-Badiola, E., Ahijado, A., 2002. Cenozoic volcanism II: the Canary Islands. In: Gibbons, W., Moreno, T. (Eds.), The Geology of Spain. The Geological Society London, pp. 439-472.

Carracedo, J.C., Pérez Torrado, F.J., Rodríguez Badiola, E., 2008. Canarias: Islas volcánicas intraplaca. In: Pérez Torrado, F.J., Cabrera, M.E. (Eds.), Itinerarios geológicos por las Islas Canarias, Gran Canaria. Geo-Guías. Sociedad Geológica de España, Las Palmas de Gran Canaria, pp. 11-25.

Chiquet, A., Michard, A., Nahon, D., Hamelin, B., 1999. Atmospheric input vs in situ weathering in the genesis of calcretes: an $\mathrm{Sr}$ isotope study at Galvez (Central Spain). Geochim. Cosmochim. Acta 63 (3-4), 311-323.

Coello, J., Cantagrel, J.-M., Hernán, F., Fúster, J.-M., Ibarrola, E., Ancochea, E., Casquet, C., Jamond, C., Díaz de Téran, J.-R., Cendrero, A., 1992. Evolution of the eastern volcanic ridge of the Canary Islands based on new K-Ar data. J. Volcanol. Geotherm. Res. 53 (1-4), 251-274.

Coudé-Gaussen, G., Rognon, P., 1988. Origine eolienne de certains encroûtements calcaires sur l'ile de fuerteventura (Canaries orientales). Geoderma 42 (3-4), 271-293.

Coudé-Gaussen, G., Rognon, P., Bergametti, G., Gomes, L., Strauss, B., Gros, J.M., Le Coustumer, M.N., 1987. Saharan dust on Fuerteventura Island (Canaries): chemical and mineralogical characteristics, air mass trajectories, and probable sources. J. Geophys. Res. 92 (D8), 9753-9771.

Criado, C., 1988. Evolución Geomorfológica de FuerteventuraPhD Thesis Universidad de La Laguna, La Laguna, Tenerife (971 pp.)

Criado, C., Dorta, P., 2003. An unusual "blood rain" over the Canary Islands (Spain). The storm of January 1999. J. Arid Environ. 55 (4), 765-783.

Criado, C., Torres, J.M., Hansen, A., Lillo, P., Naranjo, A., 2011. Intercalaciones de polvo sahariano en paleodunas bioclásticas de Fuerteventura (Islas Canarias). Cuaternario y Geomorfología 26 (1-2), 73-88.

Custodio, E., Hoppe, J., Hoyos-Limón, A., Jiménez, J., Plata, A., Udluft, P., 1987. Aportaciones al conocimiento geohidrológico de Tenerife utilizando isótopos ambientales. Hidrogeología y Recursos Hidráulicos 12, 263-280.

Damnati, B., 1997. Mineralogical and sedimentological characterization of Quaternary eolian formations and paleosols in Fuerteventura and Lanzarote (Canary Island, Spain). In: Meco, J., Petit-Maire, N. (Eds.), Climates of the Past. Servicio de Publicaciones Universidad de Las Palmas de Gran Canaria, Las Palmas de Gran Canaria, pp. 71-77.

Dart, R.C., Barovich, K.M., Chittleborough, D.J., Hill, S.M., 2007. Calcium in regolith carbonates of central and southern Australia: its source and implications for the global carbon cycle. Palaeogeogr. Palaeoclimatol. Palaeoecol. 249 (3), 322-334.
Fedoroff, N., Country, M.A., Lacroix, E., Oleschko, K., 1994. Calcitic accretion on indurated volcanic materials (example of tepetates, Altiplano, Mexico). XVth World Congress of Soil Science. Acapulco, Mexico, pp. 459-472.

Gasparini, A., Custodio, E., Fontes, J.-C., Jiménez, J., Nuñez, J.A., 1990. Exemple d'etude geochimique et isotopique de circulations aquiferes en terrain volcanique sous climat semi-aride (Amurga, Gran Canaria, Iles Canaries). J. Hydrol. 114 (1), 61-91.

Genise, J.F., Alonso-Zarza, A.M., Verde, M., Meléndez, A., 2013. Insect trace fossils in aeolian deposits and calcretes from the Canary Islands: their ichnotaxonomy, producers, and palaeoenvironmental significance. Palaeogeogr. Palaeoclimatol. Palaeoecol. 377 (1), 110-124.

Goudie, A.S., 1973. Duricrusts in Tropical and Subtropical Landscapes. Oxford Research Studies in Geography, Oxford, United Kingdom. Clarendon Press, (174 pp.).

Goudie, A.S., 1983. Calcrete. In: Goudie, A.S., Pye, K. (Eds.), Chemical Sediments and Geomorphology. Academic Press, London, pp. 93-131.

Goudie, A.S., Middleton, N.J., 2001. Saharan dust storms: nature and consequences. Earth-Sci. Rev. 56 (1), 179-204.

Graham, D.J., Midgley, N.G., 2000. Graphical representation of particle shape using triangular diagrams: an Excel spreadsheet method. Earth Surf. Process. Landf. 25 (12) 1473-1477.

Grousset, F.E., Rognon, P., Coudé-Gaussen, G., Pédemay, P., 1992. Origins of peri-Saharan dust deposits traced by their $\mathrm{Nd}$ and $\mathrm{Sr}$ isotopic composition. Palaeogeogr. Palaeoclimatol. Palaeoecol. 93 (3-4), 203-212.

Gutiérrez-Elorza, M., Lucha, P., Gracia, F.J., Desir, G., Marín, C., Petit-Maire, N., 2013. Palaeoclimatic considerations of talus flatirons and aeolian deposits in Northern Fuerteventura volcanic island (Canary Islands, Spain). Geomorphology 197, 1-9.

Hałas, S., Wołacewicz, W., 1982. The experimental study of oxygen isotope exchange reaction between dissolved bicarbonate and water. J. Chem. Phys. 76, 5470-5472.

Hamidi, E.M., Nahon, D., McKenzie, J.A., Michard, A., Colin, F., Kamel, S., 1999. Marine Sr (Ca) input in Quaternary volcanic rock weathering profiles from the Mediterranean coast of Morocco: Sr isotopic approach. Terra Nova 11 (4), 157-161.

Hamidi, E.M., Colin, F., Michard, A., Boulange, B., Nahon, D., 2001. Isotopic tracers of the origin of $\mathrm{Ca}$ in a carbonate crust from the Middle Atlas, Morocco. Chem. Geol. 176 (1-4), 93-104.

Herut, B., Starinsky, A., Katz, A., 1993. Strontium in rainwater from Israel: sources, isotopes and chemistry. Earth Planet. Sci. Lett. 120 (1), 77-84.

Hoernle, K., Carracedo, J.C., 2009. Canary Island geology. In: Gillespie, R., Clague, D.A. (Eds.), Encyclopedia of Islands. University of California Press, Berkeley, California, USA, pp. 133-143.

Khadkikar, A.S., Chamyal, L.S., Ramesh, R., 2000. The character and genesis of calcrete in Late Quaternary alluvial deposits, Gujarat, western India, and its bearing on the interpretation of ancient climates. Palaeogeogr. Palaeoclimatol. Palaeoecol. 162 (3-4) 239-261.

Khiri, F., Ezaidi, A, Kabbachi, K, 2004. Dust deposits in Souss-Massa basin, South-West of Morocco: granulometrical, mineralogical and geochemical characterisation. J. Afr. Earth Sci. 39 (3-5), 459-464

Kim, S.-T., O'Neil, J.R., 1997. Equilibrium and nonequilibrium oxygen isotope effects in synthetic carbonates. Geochim. Cosmochim. Acta 61 (16), 3461-3475.

Lal, R., Kimble, J.M., 2000. Pedogenic carbonate and the global carbon cycle. In: Lal, R. Kimble, J.M., Eswaran, H., Steward, B.A. (Eds.), Global Climate Change and Pedogenic Carbonates. Lewis Publishers, Boca Raton, FL, p. 1214.

Laurent, B., Marticorena, B., Bergametti, G., Léon, J.F., Mahowald, N.M., 2008. Modeling mineral dust emissions from the Sahara desert using new surface properties and soil database. J. Geophys. Res. 113 (D14218).

Liu, Z.H., 2011. Is pedogenic carbonate an important atmospheric $\mathrm{CO}_{2}$ sink? Chin. Sci. Bull. 56, 3794-3796.

McCrea, J.M., 1950. On the isotopic chemistry of carbonates and a paleotemperature scale. J. Chem. Phys. 18, 849-857.

Meco, J., 2008. Historia Geológica del clima en Canarias. International Union of Geological Sciences. Unesco and ULPGC, Las Palmas de Gran Canaria (296 pp.).

Meco, J., Muhs, D.R., Fontugne, M., Ramos, A.J., Lomoschitz, A., Patterson, D., 2011. Late Pliocene and Quaternary Eurasian locust infestations in the Canary Archipelago. Lethaia 44 (4), 440-454.

Meléndez, A., Alonso-Zarza, A.M., Sancho, C., 2011. Multi-storey calcrete profiles developed during the initial stages of the configuration of the Ebro Basin's exorheic fluvia network. Geomorphology 134 (3), 232-248.

Menéndez, I., Díaz-Hernández, J.L., Mangas, J., Alonso, I., Sánchez-Soto, P.J., 2007. Airborne dust accumulation and soil development in the North-East sector of Gran Canaria (Canary Islands, Spain). J. Arid Environ. 71 (1), 57-81.

Mizota, C., Matsuhisa, Y., 1995. Isotopic evidence for the eolian origin of quartz and mica in soils developed on volcanic materials in the Canary Archipelago. Geoderma 66 (3) 313-320.

Mook, W.G., Bommerson, J.C., Staverman, W.H., 1974. Carbon isotope fractionation between dissolved bicarbonate and gaseous carbon dioxide. Earth Planet. Sci. Lett. 22 (2), 169-176

Muhs, D.R., Budahn, J., Skipp, G., Prospero, J.M., Patterson, D., Bettis Iii, E.A., 2010 Geochemical and mineralogical evidence for Sahara and Sahel dust additions to Quaternary soils on Lanzarote, eastern Canary Islands, Spain. Terra Nova 22 (6), 399-410.

Ortiz, J.E., Torres, T., Yanes, Y., Castillo, C., Nuez, J.D.L., Ibáñez, M., Alonso, M.R., 2006. Climatic cycles inferred from the aminostratigraphy and aminochronology of Quaternary dunes and palaeosols from the eastern islands of the Canary Archipelago. J. Quat. Sci. 21 (3), 287-306.

Petit-Maire, N., Rosso, J.C., Delibrias, G., Meco, J., Pomel, S., 1987. Paléoclimats de l'île de Fuerteventura (Archipel Canarien). Palaeoecol. Afr. 18, 351-356.

Prospero, J.M., Lamb, P.J., 2003. African droughts and dust transport to the Caribbean: climate change implications. Science 302 (5647), 1024-1027.

Pye, K., 1987. Aeolian Dust and Dust Deposits. Academic Press, London, p. 68 (334 pp.). 
Quade, J., Cerling, T.E., Bowman, J.R., 1989. Systematic variations in the carbon and oxygen isotopic composition of pedogenic carbonate along elevation transects in the southern Great Basin, United States. Geol. Soc. Am. Bull. 101, 464-475.

Rognon, P., Coudé-Gaussen, G., 1996. Paleoclimates off Northwest Africa $\left(28^{\circ}-35^{\circ} \mathrm{N}\right)$ about 18,000 yr B.P. based on continental eolian deposits. Quat. Res. 46 (2), 118-126.

Scheuvens, D., Schütz, L., Kandler, K., Ebert, M., Weinbruch, S., 2013. Bulk composition of northern African dust and its source sediments-a compilation. Earth-Sci. Rev. 116, 170-194.

Schmincke, H.-U., Klügel, A., Hansteen, T.H., Hoernle, K., van den Bogaard, P., 1998 Samples from the Jurassic ocean crust beneath Gran Canaria, La Palma and Lanzarote (Canary Islands). Earth Planet. Sci. Lett. 163 (1-4), 343-360.

Sinha, R., Tandon, S.K., Sanyal, P., Gibling, M.R., Stuben, D., Berner, Z., Ghazanfari, P., 2006. Calcretes from a Late Quaternary interfluve in the Ganga Plains, India: carbonate types and isotopic systems in a monsoonal setting. Palaeogeogr. Palaeoclimatol. Palaeoecol. 242 (3), 214-239.

Srivastava, P., Sauer, D., 2014. Thin-section analysis of lithified paleosols from Dagshai Formation of the Himalayan Foreland: identification of paleopedogenic features and diagenetic overprinting and implications for paleoenvironmental reconstruction. $\mathrm{Ca}-$ tena $112,86-98$.

Steiner, C., Hobson, A., Favre, P., Stampfli, G., Hernández, J., 1998a. Mesozoic sequence of Fuerteventura (canary Islands): witness of Early Jurassic sea-floor spreading in the central Atlantic. Bull. Geol. Soc. Am. 110, 1304-1317.

Steiner, C., Hobson, A., Favre, P., Stampfli, G.r.M., Hernandez, J., 1998b. Mesozoic sequence of Fuerteventura (Canary Islands): witness of Early Jurassic sea-floor spreading in the central Atlantic. Geol. Soc. Am. Bull. 110 (10), 1304-1317.

Talma, A.S., Netterberg, F., 1983. Stable isotope abundances in calcretes. In: Wilson, R.C.L (Ed.), Residual Deposits: Surface Related Weathering Processes and MaterialsGeological Society, London, Special Publications. Geological Society of London, London, pp. 221-233.

Tanner, L.H., 2010. Chapter 4 Continental Carbonates as Indicators of Paleoclimate. In: Alonso-Zarza, A.M., Tanner, L.H. (Eds.), Carbonates in Continental Settings: Geochemistry, Diagenesis and Applications. Developments in Sedimentology. Elsevier, pp. 179-214.

Vallejos, A., Pulido-Bosch, A., Martin-Rosales, W., Calvache, M.L., 1997. Contribution of environmental isotopes to the understanding of complex hydrologic systems. A case study: Sierra de Gádor, SE Spain. Earth Surf. Process. Landf. 22 (12), 1157-1168.
Van der Hoven, S.J., Quade, J., 2002. Tracing spatial and temporal variations in the sources of calcium in pedogenic carbonates in a semiarid environment. Geoderma 108, 259-276.

von Suchodoletz, H., Kühn, P., Hambach, U., Dietz, M., Zöller, L., Faust, D., 2009. Loesslike and palaeosol sediments from Lanzarote (Canary Islands / Spain) - indicators of palaeoenvironmental change during the Late Quaternary. Palaeogeogr. Palaeoclimatol. Palaeoecol. 278, 71-87.

von Suchodoletz, H., Oberhänsli, H. Hambach, U., Zöller, L., Fuchs, M., Faust, D., 2010. Soil moisture fluctuations recorded in Saharan dust deposits on Lanzarote (Canary Islands) over the last 180 ka. Quat. Sci. Rev. 29 (17), 2173-2184.

von Suchodoletz, H., Blanchard, H., Hilgers, A., Radtke, U., Fuchs, M., Dietze, M., Zöller, L., 2012. TL and ESR dating of Middle Pleistocene lava flows on Lanzarote island, Canary Islands (Spain). Quat. Geochronol. 9, 54-64.

Watts, N.L., 1980. Quaternary pedogenic calcretes from the Kalahari (southern Africa): mineralogy, genesis and diagenesis. Sedimentology 27 (6), 661-686.

Whipkey, C.E., Capo, R.C., Chadwick, O.A., Stewart, B.W., 2000. The importance of sea spray to the cation budget of a coastal Hawaiian soil: a strontium isotope approach. Chem. Geol. 168, 37-48.

Wright, V.P., 2007. Calcrete. In: Nash, D.J., McLaren, S.J. (Eds.), Geochemical Sediments and Landscapes. Blackwell Publishing Ltd, Oxford, UK, pp. 10-45.

Yanes, Y., Delgado, A., Castillo, C., Alonso, M.R., Ibáñez, M., De la Nuez, J., Kowalewski, M., 2008. Stable isotope $\left(\delta^{18} \mathrm{O}, \delta^{13} \mathrm{C}\right.$, and $\left.\delta \mathrm{D}\right)$ signatures of recent terrestrial communities from a low-latitude, oceanic setting: endemic land snails, plants, rain, and carbonate sediments from the eastern Canary Islands. Chem. Geol. 249, 377-392.

Zazo, C., Hillaire-Marcel, C., Goy, J.L., Ghaleb, B., Hoyos, M., 1997. Cambios del nivel del mar-clima en los últimos 250 ka (Canarias Orientales, España). Bol. Geol. Min. 108, 487-497.

Zazo, C., Goy, J.L., Hillaire-Marcel, C., Gillot, P.Y., Soler, V., González, J.A., Dabrio, C.J., Ghaleb, B., 2002. Raised marine sequences of Lanzarote and Fuerteventura revisited - a reappraisal of relative sea-level changes and vertical movements in the eastern Canary Islands during the Quaternary. Quat. Sci. Rev. 21 (18-19), 2019-2046.

Zhang, J., Quay, P.D., Wilbur, D.O., 1995. Carbon isotope fractionation during gas-water exchange and dissolution of $\mathrm{CO}_{2}$. Geochim. Cosmochim. Acta 59 (1), 107-114. 